\section{Ankara Üniversitesi Eğitim Bilimleri Fakültesi Özel Eğitim Dergisi}

2022, 23(3), 537-563
ARAŞTIRMA

Gönderim Tarihi: 21.08.20

Kabul Tarihi: 21.09.21

Erken Görünüm: 03.11.21

\title{
Otizm Spektrum Bozukluğu Olan Çocuklara Sembolik Oyunların Öğretiminde Canlı ve Video Modelle Öğretimin Karşılaştırılması*
}

\author{
Nuray Öncül (D) 1
}

\author{
İlknur Çifci-Tekinarslan ${ }^{(D 2}$
}

$\ddot{O} \mathbf{z}$

Giriş: Otizm spektrum bozukluğu (OSB) olan çocukların sembolik oyun davranışlarının geliştirilmesinde müdahalelere ihtiyaç olduğu alanyazında belirtilmekle birlikte, çeşitli yöntemlerin etkililiği incelenmektedir. Bu araştırmanın amacı ise OSB olan çocuklara sembolik oyunların öğretiminde küçük grup öğretimi biçiminde sunulan canlı modelle öğretim ve video modelle öğretimin etkililiklerinin ve verimliliklerinin karşılaştırılmasıdır.

Yöntem: Araştırmada tek denekli araştırma modellerinden uyarlamalı dönüşümlü uygulamalar modeli kullanılmıştır. Araştırmanın canlı modelle öğretim ve video modelle öğretim olmak üzere iki bağımsız değişkeni vardır. Araştırmanın bağımlı değişkenleri ise, garsonluk ile berberlik oyunlarından oluşan sembolik oyunlardır.

Bulgular: Araştırma bulguları, küçük grup öğretimi biçiminde sunulan canlı modelle öğretim ve video modelle öğretimin OSB olan çocuklara sembolik oyunların kazandırılmasında, kazanılan sembolik oyunların öğretim sona erdikten sonra da korunmasında, farklı araç gereçlere ve kişilere genellenmesinde etkili olduğunu; edinim aşamasında video modelle ögretimin canlı modelle öğretime kıyasla, kalıcılık aşamasında ise canlı modelle öğretimin video modelle öğretime kıyasla daha etkili olduğunu; genelleme aşamasında ise canlı modelle öğretim ve video modelle öğretim arasında fark olmadığını göstermektedir.

Tartışma: OSB olan çocukların oyun özelliklerine ilişkin özellikle sembolik oyun oynamada sınırlılıkları olduğu bilinmesine rağmen, araştırmada deneklere davranış ve replik sayıları birbirine yakın senaryoya dayalı iki oyun öğretilmesi planlanmış, oyunların öğretimi küçük grup öğretimi düzenlemesi biçiminde yapılmış ve öğretim sürecinde video modelle ve canlı modelle öğretim sunularak oyunlar öğretilmiştir. Söz konusu süreçte yer alan her bir düzenleme aracılı̆̆ ile OSB olan çocukların sembolik oyunu oynamayı öğrenebilmeleri araştırmanın amacına hizmet etmektedir. Bu amaç doğrultusunda elde edilen sonuçlar ilgili alan yazın çerçevesinde tartı̧ılmış, ileride yapılacak uygulama ve araştırmalar için önerilerde bulunulmuştur.

Anahtar sözcükler: Canlı modelle öğretim, video modelle öğretim, sembolik oyun, küçük grupla öğretim, otizm spektrum bozukluğu.

Atıf için: Öncül, N., \& Çifci-Tekinarslan, İ. (2022). Otizm spektrum bozukluğu olan çocuklara sembolik oyunların öğretiminde canlı ve video modelle öğretimin karşılaştırılması. Ankara Üniversitesi Eğitim Bilimleri Fakültesi Özel Eğitim Dergisi, 23(3), 537-563. https://doi.org/10.21565/ozelegitimdergisi.783396

\footnotetext{
*Bu araştırma, Nuray Öncül tarafından Bolu Abant İzzet Baysal Üniversitesi Eğitim Bilimleri Enstitüsünde tamamlanmış doktora tezinden üretilmiştir.

${ }^{1}$ Sorumlu Yazar: Dr. Öğr. Üyesi, Anadolu Üniversitesi, E-posta: noncul@anadolu.edu.tr, https://orcid.org/0000-0003-0099$\underline{0326}$

$\frac{}{2}$ Prof. Dr., Bolu Abant İzzet Baysal Üniversitesi, E-posta: ilknur_cifci@ hotmail.com, https://orcid.org/0000-0001-5028-3289
} 


\section{Giriş}

Otizm spektrum bozukluğu (OSB), ileri düzeyde ve karmașık nörolojik bir yetersizliktir. OSB olan çocuklar, Tipik gelişim gösteren (TGG) çocuklardan farklı özellikler göstermekte ve farklı davranışlar sergilemektedirler. OSB olan çocukların sosyal etkileşim yetersizlikleri gösterdikleri, dil gelişiminde gecikmeler yaşadıkları, bilişsel gelişimde sınırlılıklar sergiledikleri, motor gelişimlerinde farklılıklar ve gecikmeler yaşadıkları, sıra dışı davranış özelliklerine sahip oldukları ve uygun biçimde oyun oynamada zorluklar yaşadıkları bilinmektedir (Bernad-Ripoll, 2007; Charlop-Christy \& Daneshvar, 2003; Kırcaali-İftar, 2013; Landa, 2007; Sucuoğlu, 2013). OSB olan çocuklar sıralanan bu özellikleri gereği kaliteli yaşama sahip olmak ve serbest zamanlarını daha keyifli geçirebilmek için desteğe gereksinim duymaktadırlar (Tekin vd., 2001).

TGG çocuklar serbest zamanlarını geçirmek üzere gerekli olan davranışları ve becerileri kendi başlarına doğal ortamlarda öğrenebilirlerken, OSB olan çocuklar bu becerileri kendiliklerinden edinip sergileyemezler. Alanyazında yapılan araştırmalar da OSB olan çocukların okul öncesi dönemdeki oyun etkinliklerinin niteliği (uygunluk, çeşitlilik, yaratıcılık, karmaşıklık) ve niceliğinin (süre, sıklık) aynı yaş grubundaki TGG ve gelişimsel yetersizliği olan akranlarından farklı olduğunu desteklemektedir (Rutherford vd., 2007). TGG çocukların okulöncesi dönemdeki oyun etkinlikleri sırasıyla nesnelerle keşfedici oyundan, nesnelere -mış gibi anlamlar yüklemeye doğru giderken (Boudreau \& D'Entrement, 2010), OSB olan çocukların oyun davranışları genel olarak tekrarlayıcı, amaç dışında oynama, yalnız oyun oynama biçiminde gözlenmektedir (Paterson \& Arco, 2007).

Uzmanlar çocukların serbest zaman ve oyun etkinliklerine katılımının önemini vurgularken, oyunun aynı zamanda çocukların fiziksel, bilişsel, duyusal, sosyal ve dil gelişimleri üzerindeki önemli katkılarını da gündeme getirmişlerdir (Morrison vd., 2002). Tüm bu katkılar oyun oynamanın, öğretim programlarında öncelikle yer alması gereken davranışlar arasında olmasını gerektirirken, oyunun çocuklar için yaşamsal öneminin olmaması ve OSB olan çocuklara oyun oynamayı öğretmenin güç görülmesinden dolayı oyun öğretimi hazırlanan eğitim programlarında ikinci planda kalabilmektedir (Massey \& Wheeler, 2000). Oysaki her çocuk gibi OSB olan çocuklar da oyun oynamaya gereksinim duyabilmektedirler.

Oyun, öğrenmeyi eğlenceli hale getiren, çocuklara bir arada keşfetmek ve yeni bir şeyler denemek için cesaret veren bir süreçtir (Singer vd., 2006; Tüfekçioğlu, 2013). Oyunlar; (a) oyunla meşgul olmama, (b) oyunu izleme, (c) yalnız oyun, (d) paralel oyun, (e) birlikte oyun ve (f) iş birlikçi oyun şeklinde sosyal gelişim temel alınarak sınıflanabileceği gibi (Bernstorf, 2012; Rubin vd., 1976; Xu, 2010); (a) işlevsel oyun, (b) yap1-inşa oyunu, (c) kurallı oyun ve (d) sembolik oyun şeklinde bilişsel gelişim temel alınarak da sınıflanabilir (Rubin vd., 1976). OSB olan çocukların her çeşit oyunu oynamada sorunlar yaşamalarının yanında özellikle sembolik oyunları oynamadaki sınırlılıkları büyük ölçüde öne çıkmaktadır (Boutot vd., 2005). Bu nedenle, OSB olan çocuklara sembolik oyunların sistematik biçimde öğretilmesi önem kazanmaktadır.

OSB olan çocukların sembolik oyun davranışlarına ilişkin yapılan çalışmalar OSB olan çocuklarda sembolik oyun oynamaya yönelik bir potansiyel olduğunu; ancak bu yeteneğin geliştirilmesinde müdahalelere ihtiyaç olduğunu ön plana çıkarmıştır (Chang vd., 2018; Rutherford vd., 2007). Alanyazında OSB olan çocukların sembolik oyun davranışlarını artırmaya veya geliştirmeye yönelik gerçekleştirilen çalışmalarda OSB olan çocukların öğretilmiş sembolik oyun davranışlarında artış olmakla beraber bazı uygulamaların OSB olan çocukların sembolik oyunlarının çeşitliliğini, karmaşıklığını, özgünlüğünü artırmada ve öğrenilen oyun becerilerini genelleyebilmelerinde etkili olduğu belirlenmiştir (Boudreau \& D'Entremont, 2010; D'Ateno vd., 2003; Ingersoll \& Schreibman, 2006; Reagon vd., 2006).

OSB olan çocuklara oyun becerilerinin öğretiminde kullanılan yöntemler arasında; ayrık denemelerle öğretim (Crocket vd., 2007), doğal öğretim yöntemleri (Garfinkle \& Schwartz, 2002; Stahmer vd., 2003), etkinlik çizelgeleriyle öğretim (Dettmer vd., 2000; Rao \& Gagie, 2006), karşılıklı taklit öğretimi (Stahmer vd., 2003), kendini yönetme (Stahmer \& Schreibman, 1992) ve modelle öğretim (Charlop-Chrsity vd., 2000; Reagon vd., 2006) yer almaktadır. Modelle öğretim bireyin, hedef davranışı sergileyen başka bir bireyi ve bireyin elde ettiği sonuçları gözlemesi ve gözlediği bu davranışı taklit ederek benzer sonuçlar elde etmesidir (Bandura vd., 1961; Schloss \& Smith, 1994; Zirpoli \& Melloy, 1997). Modelle öğretimin; (a) canlı modelle öğretim, (b) video modelle öğretim ve (c) kendi kendine video modelle öğretim olmak üzere üç farklı biçimde kullanımı söz konusudur (Graetz vd., 2006). Alanyazında canlı modelle öğretim, video modelle öğretim ve kendi kendine video modelle öğretimin OSB olan çocuklara çeşitli davranışların kazandırılmasında etkili olduğunu ortaya koyan araştırmalar olduğu gözlenmektedir. Özelikle son yıllarda, OSB olan çocuklara çeşitli davranışların kazandırılmasında video modelle öğretim ve kendi kendine video modelle öğretim kullanılarak gerçekleştirilen araştırma sayısında hızlı bir artış söz konusudur. Bu konuda yapılan araştırmalarda bir artış olsa da modelle öğretim türlerinden hangisinin 
daha etkili, daha verimli ve daha kullanıcı dostu olduğu yönünde karmaşık veriler bulunmakta ve bu yönde araştırma gereksinimi devam etmektedir (Charlop-Christy vd., 2000; Ergenekon vd., 2014; McDowell vd., 2015; Paterson \& Arco, 2007).

Alanyazında modelle öğretim türlerinin etkili olduğunu ortaya koyan araştırmaların yanı sıra OSB olan çocuklara çeşitli beceri ya da davranışların kazandırılmasında modelle öğretim türlerini birbirleriyle karşılaştırmak üzere gerçekleştirilen araştırmalar bulunmaktadır; ancak bu araştırmaların sayısı oldukça sınırlıdır. OSB olan çocuklara çeşitli becerilerin kazandırılmasında canlı modelle öğretim ile video modelle öğretimin karşılaştırıldığı altı araştırmaya (Charlop-Christy vd., 2000; Ergenekon vd., 2014; Gena vd., 2005; Odluyurt, 2013; McDowell vd., 2015; Taheri-Torbati \& Sotoodeh, 2019) video modelle öğretim ile kendi kendine video modelle öğretimin karşılaştırıldığ1 dört araştırmaya (Day, 2015; Lane, 2009; Marcus \& Wilder, 2009; Sherer vd., 2001; Wilson, 2013), canlı modelle öğretim, video modelle öğretim ve kendi kendine video modelle öğretimin karşılaştırıldığ bir araştırmaya rastlanmış (Benner, 2011) ancak canlı modelle öğretim ile kendi kendine video modelle öğretimin karşılaştırıldığı herhangi bir araştırmaya rastlanmamıştır. Dolayısıyla farklı modellemelerle yapılan öğretimlerin etkililik ve verimliliklerinin karşılaştırıldığı çeşitli araştırmalara gereksinim duyulmaktadır.

Türkiye'de gerçekleştirilen çalışmalar incelendiğinde ise, video modelle öğretim aracılığıyla sembolik oyun öğretiminin küçük grup öğretimi düzenlemesi biçiminde planlandığı bir araştırmaya (Özen vd., 2012), video modelle öğretim ve canlı modelle öğretim kullanılarak oyun öğretimine ilişkin iki araştırmaya rastlanmıştır (Ergenekon vd., 2014; Odluyurt, 2013). OSB olan çocuklara sembolik oyunların öğretiminde küçük grup öğretimi biçiminde sunulan canlı modelle öğretim ve video modelle öğretimin etkililiklerinin ve verimliliklerinin karşılaştırıldığı bir araştırmaya rastlanmamış olması bu araştırmanın planlanmasında önemli bir çıkış noktası olmuştur. Bu araştırma Özen ve diğerlerinin (2012) çalışmasından canlı modelle karşılaştırma açısından, Ergenekon ve diğerleri (2013) ve Odluyurt'un (2013) çalışmalarından ise küçük grup öğretimi yapması açısından farklılık göstermektedir. Ayrıca bahsedilen üç araştırmada öğretilen oyun becerileri açısından da farklılık göstermektedir.

Alanyazındaki araştırmaların büyük bir kısmında bire-bir öğretim düzenlemesinin kullanıldı̆̆ı; OSB olan çocuklara farklı davranışların kazandırılmasında son yıllarda bir artış da olsa belli sayıda araştırmada küçük grup öğretimi düzenlemesine yer verildiği dikkat çekmektedir (Au vd., 2016; Barton \& Ledford, 2018; Carnahan vd., 2009; Chai, 2017; Colozzi vd., 2008; Çattık \& Odluyurt, 2017; Ledford vd., 2008; Ledford \&Wehby, 2015; Nicholls, 2010; Özen vd., 2012; Palmen vd., 2008; Saadatzi vd., 2018; Tekin-İftar \& Birkan, 2010; Thompson vd., 2019). Oysa OSB olan çocukların özellikle sosyal ve dil özellikleri dikkate alındığında, bu çocukların grupla etkileşime girmesini sağlayan öğretim düzenlemelerine gerek olduğu söylenebilir. Ayrıca birebir öğretim düzenlemesi oldukça maliyetli ve zaman alıcı bir düzenlemedir; ancak uygulama ortamlarında daha verimli ve uygulamacı dostu öğretim düzenlemelerine gerek vardır (Hill \& Gutwin, 2004; Wolery vd.,1992). Küçük grup öğretiminin birebir öğretime göre bazı üstünlükleri vardır. Birincisi, çocukları toplumsal ortamlar ya da genel eğitim sınıfları gibi farklı ortamlara hazırlar. İkincisi, öğretmen aynı anda birden fazla çocuğa öğretim sunduğu için öğretim zamanının verimli kullanılmasını sağlar (Wolery vd., 1992). Üçüncüsü, grup içindeki çocukların birbirleri ile etkileşime girmelerine ve işbirliği yapmalarına ya da birbirlerine yardım etmelerine ve destek olmalarına katkıda bulunur. Dördüncüsü, grup içindeki diğer çocuklara öğretilen beceri ve davranışların gözleyerek öğrenme yoluyla öğrenilmesini sağlar (Chai, 2017; Collins vd., 1991; Doyle vd., 1990; Farmer vd., 1991; Ledford \& Wehby, 2015; Wolery vd., 1992). Beşincisi, daha az personel ve öğretim zamanı gerektirir (Barton \& Ledford, 2018; Collins vd., 1992; Gürsel vd., 2006; Tekin-İftar \& Birkan, 2010). Altıncısı, çocukların kendini yönetme ve problem çözme becerilerinin gelişimine katkıda bulunur (Hill \& Gutvin, 2004; Lusardi vd., 2002; Shelton vd., 1991).

Oyun becerilerinin öğretimi OSB olan çocukların sosyal ve iletişim becerilerinin geliştirilmesinde önemli bir yere sahiptir. Bu nedenle oyun becerileri OSB olan çocuklara kazandırılması gereken öncelikli beceriler arasında yer almalıdır. Buna karşın alanyazındaki araştırmalar OSB olan çocuklara oyun becerilerinin öğretimi açısından incelendiğinde oyun becerilerinin özellikle de OSB olan çocukların en çok zorlandıkları video modelle öğretim ve canlı modelle öğretimin karşılaştırılarak planlandığı; sembolik oyun becerilerinin öğretiminin yapıldı̆̆ araştırmalara halen gereksinim olduğu söylenebilir.

$\mathrm{Bu}$ araştırmanın özgün bir diğer noktası da modelle öğretimin yanı sıra ipucu ve pekiştirmenin kullanılmamasıdır. Bu nokta özellikle modelle öğretim türlerinin etkililiğinin araştırıldığı araştırmalarda vurgulanmakta, modelle öğretimin yanı sıra ipucu ve pekiştirme gibi ek düzenlemelerin kullanıp kullanılmaması tartış1lmaktadır (Allen vd., 2010; Charlop vd., 2010; MacDonald vd., 2005; Macdonald vd., 2009; Reagon vd., 
2006). Çünkü etkililik bulgularının modelle öğretimden mi yoksa modelle öğretimin yanı sıra kullanılan ipucu ve pekiştirmeden mi kaynaklandığına karar vermek zor olabilmektedir. $\mathrm{Bu}$ nedenle, ipucu ve pekiştirme kullanılmaksızın yalnızca modelle öğretimin kullanıldığı araştırmalara gerek duyulmaktadır. Bu araştırmanın da bu gereksinime yanıt verebileceği düşünülmektedir.

$\mathrm{Bu}$ araştırmanın amacı, OSB olan çocuklara sembolik oyunların öğretiminde küçük grup öğretimi biçiminde sunulan canlı modelle öğretim ve video modelle öğretimin etkililiklerinin ve verimliliklerinin karşılaştırılmasıdır. Bu amaca ulaşmak üzere şu sorulara yanıt aranmıştır.

1. OSB olan çocuklara sembolik oyunların öğretiminde küçük grup öğretimi biçiminde sunulan canlı modelle öğretim ve video modelle öğretimin edinim, izleme ve genelleme aşamasında etkililikleri farklılaşmakta mıdır?

2. OSB olan çocuklara sembolik oyun becerilerinin öğretiminde küçük grup öğretimi biçiminde sunulan canlı modelle öğretim ve video modelle öğretim ölçüt karşılanıncaya değin gerçekleşen; deneme sayısı, oturum sayısı, hata sayısı ve toplam öğretim süresi açısından farklılaşmakta mıdır?

3. OSB olan çocuklara sembolik oyunların öğretiminde küçük grup öğretimi biçiminde sunulan canlı modelle öğretim ve video modelle öğretim sırasında gözleyerek öğrenme gerçekleşmekte midir?

4. Araştırmada belirlenen amaçların, kullanılan yöntemin ve elde edilen sonuçların anlamlılığına ilişkin doğrudan tüketicilerden (deneklerin kendileri) öznel değerlendirme yolu ile toplanan sosyal geçerlik verisi nasıldır?

5. Araştırmada belirlenen amaçların, kullanılan yöntemin ve elde edilen sonuçların anlamlılığına ilişkin yakın toplum üyelerinden (öğretmen adayları) öznel değerlendirme yolu ile toplanan sosyal geçerlik verileri nasıldır?

\section{Yöntem}

Araştırmanın bu bölümünde; katılımcılar, ortam, araç gereçler, araştırma modeli, bağımlı değişken, bağımsız değişken, deney süreci, verilerin toplanması ve verilerin analizine ilişkin bilgilere yer verilmiştir.

\section{Araştırma Modeli}

Araştırmada, OSB olan çocuklara sembolik oyun becerilerinin öğretiminde küçük grup öğretimi biçiminde gerçekleştirilen canlı modelle öğretim ve video modelle öğretimin etkililik ve verimliliklerini karşılaştırmak üzere tek-denekli araştırma modellerinden uyarlamalı dönüşümlü uygulamalar modeli kullanılmıştır (Holcombe vd., 1994; Tekin-İftar, 2012). Araştırmada uyarlamalı dönüşümlü uygulamalar modelinin gereklerini yerine getirmek üzere; (a) bağımlı değişkenler eşit zorluk düzeyinde ve işlevsel olarak birbirine benzer; ancak birbirinden bağımsız olacak biçimde seçilmiş, (b) hangi bağımlı değişkenin hangi bağımsız değişken ile eşleşeceğini belirlemek üzere yansız atama yapılmış, (c) bağımsız değişkenlerin dönüşümü gün içinde tüm bağımsız değişkenler uygulanacak biçimde hızlıca gerçekleştirilmiş, (d) bağımsız değişkenlerin uygulanma sırası yansız atama yoluyla her seferinde değiştirilerek gerçekleştirilmiş, (e) tüm bağımsız değişkenlerle eşit sayıda uygulama gerçekleştirilmiş ve (f) bağımsız değişkenler ile bağımlı değişkenler arasındaki işlevsel ilişkiyi belirleyebilmek amacıyla bağımsız değişkenler dışında herhangi bir ek uygulama gerçekleştirilmemiştir. Bu modelde araştırmada, kazandırılması hedeflenen bağımlı değişkenlerin basamak sayıları ve gerektirdikleri davranışlar mantıksal analiz yapılarak eşitlenmeye çalışılmış ve bağımlı değişkenlerin eşit zorluk düzeyinde oldukları varsayılmıştır.

\section{Katılımelar}

Bu araştırmanın katılımcıları; OSB olan üç çocuk, canlı model olarak görev alan üç öğretmen adayı, video model olarak görev alan üç araştırma görevlisi, araştırmanın sosyal geçerliğine ilişkin görüş bildiren 64 öğretmen adayı ve uygulamacıdan oluşmaktadır. İzleyen bölümde araştırmanın katılımcıları hakkında ayrıntılı bilgilere yer verilmiştir.

\section{Denekler}

$\mathrm{Bu}$ araş̧ırmaya denek olarak, OSB olan üç erkek çocuk katılmıştır. Deneklerin üçü de Eskişehir İli Tepebaşı İlçesinde bulunan ve OSB olan çocukların devam ettiği Özel Eğitim Uygulama Merkezinden seçilmiştir. Araştırmaya katılabilmeleri için deneklerden bazı önkoşullara sahip olmaları beklenmiştir. Bunlar; a) OSB dışında gelişimsel yetersizlik tanısı almamış olmak, b) en az 5 dakika süreyle etkinliğe katılmak, c) en az 5 dakika süreyle 
video görüntüsü izlemek, d) sözel yönergeleri yerine getirmek e) motor ve sözel davranışları taklit etmek, f) grup etkinliklerinde sıra almak, g) okula düzenli devam etmek. İzleyen bölümde deneklerin özellikleri ayrıntılı biçimde Tablo 1'de açıklanmıştır.

\section{Tablo 1}

Araştırmaya Katılan Deneklerin Özellikleri

\begin{tabular}{ccccc}
\hline Adı & Cinsiyeti & Yaşı & Tanısı & Eğitim süresi \\
\hline Kaan & Erkek & 11 yaş 7 ay & Yaygın gelişimsel bozukluk & 5 yıl \\
Salih & Erkek & 11 yaş 7 ay & Otizm & 5 yıl \\
Selim & Erkek & 11 yaş 8 ay & Otizm & 5 yıl \\
\hline
\end{tabular}

Kaan, yaygın gelişimsel bozukluk tanısı almış 11 yaşında bir erkek öğrencidir. Kaan; grup etkinliklerine katılma, paylaşma, yardım etme ve iş birliği yapma gibi sosyal becerileri sergilemektedir. En az üç sözcükten oluşan taklit becerilerini yerine getirebilmekte ve yalnız oyun ve paralel oyun oynayabilmekte; ancak sembolik oyun becerilerinde güçlükler yaşamaktadır.

Salih, otizm tanısı almış 11 yaşında bir erkek öğrencidir. Salih; söylenen yönergeleri yerine getirme, sıra alma, iletişim başlatma ve sürdürme gibi alıcı ve ifade edici dil becerilerini yerine getirmektedir. Grup etkinliklerine katılabilmekte, yalnız oyun ve paralel oyun oynayabilmekte; ancak sembolik oyun becerilerinde güçlükler yaşamaktadır.

Selim, otizm tanısı almış 11 yaşında bir erkek öğrencidir. Selim; sıra alma, iletişim başlatma ve sürdürme gibi alıcı ve ifade edici dil becerilerini yerine getirmekte, paralel oyun oynayabilmekte; sembolik oyun becerilerinde ise güçlükler yaşamaktadır. Selim ayrıca grup etkinliklerine aktif biçimde katılabilmektedir.

\section{Modeller}

Araştırmanın canlı modelle öğretim ve video modelle öğretim süreçlerinde hedef davranışları gerçekleştirmek üzere modeller görev almıştır. Canlı modelle öğretimde yer alan modeller, deneklerin tanıdıkları yetişkinler arasından seçilmiştir. Seçilen modeller, Zihin Engelliler Öğretmenliği Lisans Programı'nda son sınıf öğrencisi olan ve aynı zamanda deneklerin devam ettikleri okulda Öğretmenlik Uygulaması dersini alan üç erkek yetişkindir. Araştırmanın canlı modelle öğretim oturumlarına başlamadan önce garsonluk oyununa uygun biçimde hazırlanmış senaryo modellere verilmiş ve modellerden her birine rolleri dağıtılmıştır. Modeller birkaç gün bu senaryo üzerinde rollerine çalışmışlar ve sonrasında araştırmacının kontrolünde garsonluk oyununu prova etmişlerdir.

Video modelle öğretimde yer alan modeller, deneklerin tanımadıkları yetişkinler arasından seçilmiştir. Seçilen modeller, Zihin Engelliler Öğretmenliği Yüksek Lisans Programı'nda öğrenci olan ve aynı zamanda Özel Eğitim Bölümü'nde araştırma görevlisi olarak görev yapan üç erkek yetişkindir. Araştırmanın video modelle öğretim oturumlarına başlamadan önce berberlik oyununa uygun biçimde hazırlanmış senaryo modellere verilmiş ve modellerden her birine rolleri dağıtılmıştır. Modeller birkaç gün bu senaryo üzerinde rollerine çalışmışlar ve sonrasında araştırmacının kontrolünde berberlik oyununu prova etmişlerdir. Araştırmada yer alan modellerin özellikleri Tablo 2' de yer almaktadır.

\section{Uzmanlar}

$\mathrm{Bu}$ araştırmanın gerçekleştirilmesinde toplam 18 uzmandan destek alınmıştır. Bu uzmanlar uzmanlık alanları doğrultusunda; deneklere öğretilecek oyunların senaryolarının hazırlanmasında, araştırmacı ile birlikte Okulöncesi Eğitimi Bilim Dalından doktora derecesine sahip bir uzman görev almıştır. Senaryoların hazırlanmasında görev alan uzman; çocuklar tarafından en çok tercih edilen oyunların belirlenmesi, oyunlarda yer alacak rollerin seçilmesi ve belirlenen oyunlar doğrultusunda senaryoların yazılması konularında araştırmaya destek vermiştir.

Deneklere öğretilecek oyunların senaryoları hazırlandıktan sonra hazırlanan olası senaryolara ilişkin beş, farklı üniversiteden ve bir üniversite dışı kurumdan olmak üzere on farklı uzmandan görüş, alınmıştır. Bu uzmanlardan üçü Zihin Engellilerin Eğitimi Bilim Dalından doktora derecesine sahip olup aynı zamanda araştırmacının tez izleme komitesinde yer almaktadırlar.

Araştırmada sosyal geçerlik verilerini toplamak üzere hazırlanan soruların içerik ve görünüş geçerliğini belirlemek üzere dört farklı üniversiteden olmak üzere altı farklı uzmandan görüş, alınmıştır. Bu uzmanlardan beşi 
Zihin Engellilerin Eğitimi Bilim Dalından doktora derecesine, biri ise Zihin Engellilerin Eğitimi Bilim Dalından yüksek lisans derecesine sahiplerdir.

Araştırmada gözlemciler arası güvenirlik, uygulama güvenirliği ve sosyal geçerlik verilerinin toplanmasında iki uzman görev almıştır. Araştırmanın bağımlı değişkenlerine ilişkin gözlemciler arası güvenirlik verileri ile bağımsız değişkenlerine ilişkin uygulama güvenirliği verileri Ortaöğretim Alan Öğretmenliği Bilim Dalından yüksek lisans derecesine sahip bir uzman tarafından toplanmıştır. Araştırmanın sosyal geçerlik verilerine ilişkin güvenirlik verileri ise Zihin Engellilerin Eğitimi Bilim Dalından doktora derecesine sahip bir uzman tarafından toplanmıştır.

Tablo 2

Araştırmada Görev Alan Modellerin Özellikleri

\begin{tabular}{ccccc}
\hline \multicolumn{5}{c}{ Garsonluk oyununda görev alan canlı modeller } \\
\hline Adı & Cinsiyeti & Yaşı & Görevi & Rolü \\
\hline Selçuk & Erkek & 24 & Lisans öğrencisi & İşletme müdürü \\
Anıl & Erkek & 23 & Lisans öğrencisi & Garson \\
Aras & Erkek & 23 & Lisans öğrencisi & Müşteri \\
\hline Adı & \multicolumn{2}{c}{ Berberlik oyununda görev alan video modeller } & Rolü \\
\hline Eren & Cinsiyeti & Yaşı & Görevi & Berber \\
Arda & Erkek & 29 & Araştırma görevlisi & Çı̈rak \\
Mert & Erkek & 28 & Araştırma görevlisi & Müşteri \\
\hline
\end{tabular}

\section{Ortam ve Araç-Gereçler}

Araştırma, Eskişehir ili Tepebaşı ilçesinde bulunan ve OSB olan çocukların devam ettiği özel eğitim uygulama merkezinde yürütülmüş̧ür. Araştırmanın tüm oturumları (başlama düzeyi, öğretim, doğal yoklama, genelleme, izleme ve gözleyerek öğrenmeyi yoklama oturumları) okulda bulunan ve "uygulama evi" olarak adlandırılan $10 \mathrm{~m}^{2}$ büyüklüğünde bir sınıfta gerçekleştirilmiştir. Araç gereçleri senaryolar, video görüntüsü, oyunlarda kullanılan araç gereçler ve veri toplamada kullanılan araç gereçler olarak sınıflandırmak mümkündür. Garsonluk oyunu için (masa, sandalye, tabak, çatal, bıçak, peçete, vb.), berberlik oyunu için (önlük, tarak, makas, fırça, şampuan vb.) gerekli olan araç gereçler deney sürecinde kullanılmıştır.

\section{Bağımlı ve Bağımsız Değişkenler}

$\mathrm{Bu}$ araştırmanın bağımlı değişkenleri deneklerin gereksinimleri ve özellikleri dikkate alınarak belirlenmiş olan, karşılıklı etkileşim gerektiren ve garsonluk ile berberlik oyunlarından oluşan sembolik oyunlardır. Bu araştırmada garsonluk ve berberlik oyunları; ortamın berber salonu ya da restoran biçiminde düzenlendiği, gerçek nesneleri temsil eden oyuncakların ya da oyuncakların bulunamadığ durumlarda gerçek nesnelerin kullanıldığı, berber, müşteri ve çırak ya da işletme müdürü, müşteri ve garson rollerinin taklit edilerek temsil edildiği sembolik oyunlardır. Garsonluk ve berberlik oyunları için her role ilişkin davranışların ve repliklerin yer aldığı beceri analizleri kullanılmıştır. Garsonluk oyununun beceri analizinde, müdür rolündeki çocuğun kapının yanında durması, garson rolündeki çocuğun tezgâhın arkasında durması ve müşteri rolündeki çocuğun ise restorana girmesi beklenir. Berberlik oyununda ise, çırak rolündeki çocuğun yerleri süpürmesi, berber rolündeki çocuğun sandalyede oturması, müşteri rolündeki çocuğun dükkâna girmesinin beklenmesi öğrenci tepkilerine örnek olarak verilebilir.

$\mathrm{Bu}$ araştırmada garsonluk ve berberlik oyunları; ortamın berber salonu ya da restoran biçiminde düzenlendiği, gerçek nesneleri temsil eden oyuncakların ya da oyuncakların bulunamadığ durumlarda gerçek nesnelerin kullanıldığı, berber, müşteri ve çırak ya da işletme müdürü, müşteri ve garson rollerinin taklit edilerek temsil edildiği sembolik oyunlardır. Araştırmanın canlı modelle öğretim ve video modelle öğretim olmak üzere iki bağımsız değişkeni vardır.

\section{Deney Süreci}

OSB olan çocuklara sembolik oyun becerilerinin öğretiminde küçük grup öğretimi biçiminde gerçekleştirilen canlı modelle öğretim ve video modelle öğretimin etkililik ve verimliliklerinin karşılaştırıldığı bu araştırmanın deney süreci; (a) başlama düzeyi oturumları, (b) öğretim oturumları, (c) doğal yoklama oturumları (d) genelleme oturumları (e) izleme oturumları ve (f) gözleyerek öğrenmeyi yoklama oturumlarından 
oluşmaktadır. Deney sürecinde tüm oturumlar küçük grup öğretimi biçiminde gerçekleştirilmiştir. Hem canlı modelle öğretim hem de video modelle öğretim oturumları sabah ve öğleden sonra olmak üzere günde ikişer oturum olacak biçimde haftanın üç günü yürütülmüştür. Her öğretim oturumunda birer deneme gerçekleştirilmiştir. Yanıt aralığı beş saniye olarak belirlenmiştir. Deneysel kontrolü sağlamak yani bağımlı değişkendeki değişikliğin yalnızca bağımsız değişkenden kaynaklandığını ortaya koymak üzere, deney sürecindeki oturumların tümünde deneklere herhangi bir ipucu, dönüt ya da pekiştireç sunulmamıştır.

\section{Başlama Düzeyi Oturumları}

Öğretime başlamadan önce deneklerin hem garsonluk hem de berberlik oyunlarına ilişkin performanslarını belirlemek üzere başlama düzeyi oturumları düzenlenmiştir. Başlama düzeyi oturumları küçük grup düzenlemesi biçiminde gerçekleştirilmiş ve bu oturumlarda her bir oyun için tek bir deneme yapılmıştır. Başlama düzeyi oturumlarında; (a) oyun için gerekli ortamın düzenlemesi yapılmış, (b) oyun için gerekli malzemeler ve oyuncaklar hazırlanmış, (c) deneklere oyundaki rolleri dağıtılmış, (d) gruba yönelik dikkati sağlayıcı ipucu sunulmuş, (e) hedef uyaran (beceri yönergesi) sunulmuş, (f) yanıt aralı̆̆ beklenmiş ve (g) deneklerin uygun tepkide bulunup bulunmadıkları gözlenerek oturum sürdürülmüş ya da sonlandırılmıştır. Başlama düzeyi oturumlarında deneklere doğru ya da yanlış tepkileri için hiçbir ipucu, dönüt ya da pekiştireç sunulmamıştır. Başlama düzeyi oturumları, en az üç oturum üst üste kararlı veri elde edilinceye kadar devam etmiştir.

\section{Öğretim Oturumları}

Canlı modelle öğretim ve video modelle öğretimin uygulanma sırası yansız atama yoluyla gerçekleştirilmiştir. Canlı modelle öğretimde, denekler canlı modellerin tümünü aynı anda görebilecek biçimde sınıfta bulunan üçlü koltukta yan yana oturmuşlar, modeller ise deneklerin karşısında olacak biçimde oyundaki yerlerini almışlardır. Araştırmacı deneklerin dikkatini çalışmaya çekmiş ve deneklere, yapılacakları dikkatle izlemeleri için yönerge vermiştir (ör. Çocuklar, çalışmaya hazır olduğunuzu görüyorum. Şimdi yapılacakları dikkatlice izleyin). Deneklerin, modellerin oynayacakları oyunu izlemeye hazır oldukları gözlendikten sonra modellere oyuna başlamaları için hedef uyaran sunulmuştur (ör. Arkadaşlar, garsonluk oynayın.). Modeller garsonluk oyununu oynarken deneklerin modelleri izlemeleri sağlanmıştır. Oyun oynanırken deneklerin dikkatini başka yöne yöneltmeleri durumunda modelleri izlemeleri için deneklere ipucu sunulmuştur (ör. Selim, öğretmenlerine bak. Şu anda oyunu izliyorsun.). Deneklerin garsonluk oyunu tamamlanıncaya kadar modelleri izlemeleri sağlanmıştır. Modeller garsonluk oyununu tamamladıktan sonra doğal yoklama oturumları gerçekleştirilmiş ve doğal yoklama oturumlarında deneklerin garsonluk oyununu bağımsız biçimde oynamaları için firsat verilmiştir.

Video modelle öğretimde denekler masanın karşısına konulmuş sandalyelerde yan yana oturmuşlar, video görüntüsünün izleneceği dizüstü bilgisayar deneklerin karşısındaki masada olacak biçimde yerleştirilmiştir. Araştırmacı deneklerin dikkatini çalışmaya çekmiş ve deneklere, video görüntüsünü dikkatle izlemeleri için yönerge vermiştir (ör. Çocuklar, çalışmaya hazır olduğunuzu görüyorum. Şimdi video görüntüsünü dikkatlice izleyin). Deneklerin, video görüntüsünü izlemeye hazır oldukları gözlendikten sonra araştırmacı ya da deneklerden birisi video görüntüsünü başlatmıştır (ör. Şimdi görüntüyü açalım.). Video görüntüsünde berberlik oyunu oynanırken deneklerin video görüntüsünü izlemeleri sağlanmıştır. Video görüntüsü devam ederken deneklerin dikkatini başka yöne yöneltmeleri durumunda görüntüyü izlemeleri için deneklere ipucu sunulmuştur (ör. Selim, video görüntüsüne bak. Şu anda oyunu izliyorsun.). Deneklerin berberlik oyunu tamamlanıncaya kadar video görüntüsünü izlemeleri sağlanmıştır. Video görüntüsü bittikten sonra doğal yoklama oturumları gerçekleştirilmiş ve doğal yoklama oturumlarında deneklerin berberlik oyununu bağımsız biçimde oynamaları için fırsat verilmiştir.

\section{Doğal Yoklama Oturumlart}

Doğal yoklama oturumları, deney sürecinde her iki öğretim uygulamasıyla öğretimi yapılan garsonluk ve berberlik oyunlarına ilişkin deneklerin performans düzeylerini belirlemek amacıyla düzenlenmiştir. Doğal yoklama oturumları her öğretim oturumundan hemen sonra gerçekleştirilmiştir. Doğal yoklama oturumlarında başlama düzeyi oturumlarında izlenen sürecin aynısı izlenmiştir. Bu oturumlarda elde edilen verilerin kaydı öğretim verisi olarak kullanılmıştır.

\section{Genelleme Oturumlart}

Araştırmada deneklerin öğrendikleri oyunları farklı kişilerin varlığında ve farklı araç-gereçlerle gerçekleştirip gerçekleştirmediklerini belirlemek üzere genelleme oturumları düzenlenmiştir. Genelleme 
oturumları öntest ve sontest oturumları biçiminde, başlama düzeyi oturumları gibi gerçekleştirilmiştir. Ön test oturumları öğretim oturumlarından önce, son test oturumları ise öğretim oturumlarından sonra düzenlenmiştir. Genelleme oturumlarında araştırmacıdan farklı olarak okuldaki öğretmenlerden biri görev almış, ayrıca öğretimde kullanılan araç gereçlerden farklı renkte, farklı büyüklükte ve farklı materyallerden yapılmış araç gereçler kullanılmıştır. Örneğin; öğretim ve doğal yoklama oturumlarına hamurdan yapılmış olan pizza, genelleme oturumlarında maket biçiminde kullanılmıştır.

\section{İzleme Oturumlart}

Araştırmada deneklerin öğrendikleri oyunları öğretim sona erdikten sonra ne düzeyde koruduklarını belirlemek amacıyla izleme oturumları düzenlenmiştir. İzleme oturumları öğretim sona erdikten 10 gün sonra gerçekleştirilmiştir. İzleme oturumları başlama düzeyi oturumları gibi yürütülmüştür.

\section{Gözleyerek Öğrenmeyi Yoklama Oturumlart}

Araştırmada, gözleyerek öğrenmenin gerçekleşip gerçekleşmediğini, gerçekleşti ise ne düzeyde gerçekleştiğini belirlemek üzere gözleyerek öğrenmeyi yoklama oturumları düzenlenmiştir. Gözleyerek öğrenmeyi yoklama oturumlarında, her bir deneğe sırayla kendi rolü dışındaki diğer iki rol verilmiş ve deneklerin kendi rolleri dişındaki diğer rolleri gözleyerek öğrenip öğrenmedikleri sınanmıştır. Gözleyerek öğrenme oturumları; ön test oturumları, yoklama oturumları (1. yoklama, 2. yoklama ve 3. yoklama oturumları) ve son test oturumları biçiminde başlama düzeyi oturumları gibi gerçekleştirilmiştir. Ön test oturumları öğretim oturumlarından önce, yoklama oturumları deneklerin tümü kendi rollerinde $\% 80$ ve üstünde performans sergilemeye başladıktan sonra, son test oturumları ise öğretim oturumlarında ölçüt karşılandıktan sonra yapılmıştır. Gözleyerek öğrenme deneklerin rollerini sergileme sırasında birbirlerini izlemeleri biçiminde gerçekleşmiştir.

\section{Verilerin Toplanması ve Analizi}

$\mathrm{Bu}$ araştırmada etkililik verileri, verimlilik verileri, sosyal geçerlik verileri ve güvenirlik verileri olmak üzere dört tür veri toplanmıştır. Güvenirlik verileri dışındaki tüm veriler ilgili veri toplama formları kullanılarak araştırmacı tarafından toplanmıştır. Etkililik verilerinin toplanmasında, garsonluk ve berberlik oyunlarının senaryolarına dayanılarak hazırlanan ve bağımlı değişken başlığı altında yer alan beceri analizleri dikkate alınarak beceri analizi kaydı yapılmıştır. Verilerin toplanmasında Başlama Düzeyi, Doğal Yoklama, Genelleme, İzleme ve Gözleyerek Öğrenmeyi Yoklama Oturumları Veri Toplama Formu kullanılmıştır. Veriler toplanırken deneklerin rollerine ilişkin sergiledikleri doğru tepkiler (+), yanlış tepkiler (-) sembolleri kullanılarak kaydedilmiştir.

Verimlilik verileri ise, (a) ölçüt karşılanıncaya değin gerçekleşen deneme sayısı, (b) ölçüt karşılanıncaya değin gerçekleşen oturum sayısı, (c) ölçüt karşılanıncaya değin gerçekleşen hata sayısı ve (d) ölçüt karşılanıncaya değin gerçekleşen toplam öğretim süresine ilişkin toplanmıştır. Araştırmada oturumlar küçük grup düzenlemesi biçiminde gerçekleştirildiği için bir denekte ölçüt karşılansa da öğretim oturumları sonlandırılmamış, deneklerin tamamında ölçüt karşılanıncaya değin öğretim devam etmiştir. Bu nedenle, bazı deneklerde ölçüt karşılandıktan sonra da öğretime devam edilmesine karşın verimliliği belirlemek üzere yalnızca ölçüt karşılanıncaya değin gerçekleşen deneme sayısı, oturum sayısı, hata sayısı ve toplam öğretim süresi dikkate alınmıştır.

$\mathrm{Bu}$ araştırmada etkililik verileri, verimlilik verileri, sosyal geçerlik verileri ve güvenirlik verileri olmak üzere dört tür veri analiz edilmiştir. Araştırmada elde edilen verilerin etkililiği görsel analiz ve etki büyüklüğü hesaplaması olmak üzere iki biçimde analiz edilmiştir. Görsel analizde, öncelikle her bir bağımlı değişken için Doğru tepki yüzdesi = $($ Doğru tepki sayısı) $/$ (Toplam tepki fırsatı) x 100 formülü kullanılarak deneklerin doğru tepki yüzdeleri hesaplanmıştır (Tekin-İftar, 2012). Her bir denekte her bir bağımlı değişken için elde edilen doğru tepki yüzdeleri çizgi grafiklerine aktarılmıştır.

Araştırmada canlı modelle öğretim ve video modelle öğretim arasında verimlilik açısından bir fark olup olmadığını belirlemek üzere; (a) ölçüt karşılanıncaya değin gerçekleşen deneme sayısı, (b) ölçüt karşılanıncaya değin gerçekleşen oturum sayısı (c) ölçüt karşılanıncaya değin gerçekleşen hata sayısı ve (c) ölçüt karşılanıncaya değin gerçekleşen toplam öğretim süresine ilişkin toplanan veriler betimsel olarak analiz edilmiştir.

Sosyal geçerliğe ilişkin veriler betimsel analiz yoluyla nicel olarak analiz edilmiştir. Analiz için öncelikle öğretmen adaylarından toplanan yazılı sosyal geçerlik soru formları araştırmacı tarafından tek tek okunarak tüm formlara ilişkin genel bir görüş elde edilmiştir. Daha sonra her bir soru maddesinin altında yer alabilecek temalar belirlenmiş ve bu temalar doğrultusunda bir kodlama anahtarı oluşturulmuştur. Bu kodlama anahtarı dikkate alınarak her bir soru formu araştırmacı tarafından tek tek incelenmiş ve öğretmen adayları tarafından sorulara 
verilen yanıtlar uygun biçimde kodlama anahtarına işaretlenmiştir. Daha sonra, yapılan bu kodlamalara ilişkin değerlendiriciler arası güvenirlik analizi yapılmıştır.

Araştırma sürecinde gerçekleştirilen tüm oturumların \%100’ünde gözlemciler arası güvenirlik verisi, \%30'undan uygulama güvenirliği verisi ve öğretmen adaylarından elde edilen sosyal geçerlik verilerinin \%30'una ilişkin değerlendiriciler arası güvenirlik verisi toplanmıştır. Araştırmanın başlama düzeyi, doğal yoklama, genelleme, izleme ve gözleyerek öğrenme yoklama oturumlarına ilişkin uygulama güvenirliği \% 100 bulunmuştur. Sosyal geçerlik sorularına ilişkin değerlendiriciler arası güvenirlik analizinde 2 . ve 8 . soru hariç tüm sorularda $\% 100$ güvenirlik sağlanırken 2 . soruda $\% 88,8$. soruda ise $\% 75$ düzeyinde güvenirlik sağlanmıştır.

\section{Bulgular}

$\mathrm{Bu}$ bölümde, OSB olan çocuklara sembolik oyunların öğretiminde küçük grup öğretimi biçiminde sunulan canlı modelle öğretim ile video modelle ögretimin etkililiklerine ve verimliliklerine, deneklerin gözleyerek öğrenmelerine ve sosyal geçerliğe ilişkin bulgular yer almaktadır.

\section{Etkililik Bulguları}

Araştırmada yer alan deneklerin sembolik oyunları küçük grup öğretimi biçiminde sunulan canlı modelle öğretim ve video modelle öğretim kullanılarak öğrenmelerine ilişkin bulgular Kaan, Salih ve Selim için sırasıyla Şekil 1, 2, 3’te yer almaktadır. Her bir denek için etkililik verileri çizgi grafiği kullanılarak, ifade edilmiştir. Çizgi grafiğinde başlama düzeyi, uygulama ve izleme oturumlarına ilişskin veriler yer almıştır. Başlama düzeyi evresindeki veriler öğretim oturumları başlamadan önce gerçekleştirilen başlama düzeyi oturumlarında toplanan verilerden, uygulama evresindeki veriler her öğretim oturumundan sonra gerçekleştirilen doğal yoklama oturumlarında toplanan verilerden, izleme evresindeki veriler ise öğretim sona erdikten 10 gün sonra gerçekleştirilen izleme oturumlarındaki verilerden oluşmaktadır. Araştırmanın bağımlı değişkenleri ile bağımsız değişkenleri arasındaki işlevsel ilişkinin büyüklüğüne ilişsin Ortancayı Aşan Veri Yüzdesi (OAVY) hesaplama sonuçları ise her bir denek ve her bir bağımsız değişken için ayrı ayrı açıklanmıştır.

Kaan'ın sembolik oyun becerilerine ilişkin başlama düzeyi, uygulama ve izleme evrelerinden elde edilen veriler Şekil 1'de gösterilmektedir. Şekil 1'de de görüldüğü gibi Kaan'ın başlama düzeyi evresinde hem garsonluk hem de berberlik oyununa ilişkin performans düzeyi \%0'dır. Kaan'ın uygulama evresinde her iki oyunda da ilerleme sergilediği ve ölçütü karşılayarak \%85 düzeyinde doğru tepkide bulunduğu; izleme evresinde ise garsonluk oyununu \%100, berberlik oyununu \%85.7 düzeyinde koruduğu görülmektedir.

Kaan; canlı modelle öğretimin sunulduğu 30 öğretim oturumu sonunda garsonluk oyununda, video modelle öğretimin sunulduğu 28 öğretim oturumu sonunda berberlik oyununda üç oturum ard arda \%85 ve üzerinde performans sergileyerek ölçütü karşılamıştır. İşlevsel ilişkinin büyüklüğünü belirlemek üzere gerçekleştirilen OAVY hesaplaması sonucu canlı model için \% 80, video model için \%100 bulunmuştur. 


\section{Şekil 1}

Kaan’ın Başlama Düzeyi, Uygulama ve İzleme Evrelerinde Berberlik ve Garsonluk Oyunlarına İlişkin Doğru Tepki Yüzdeleri

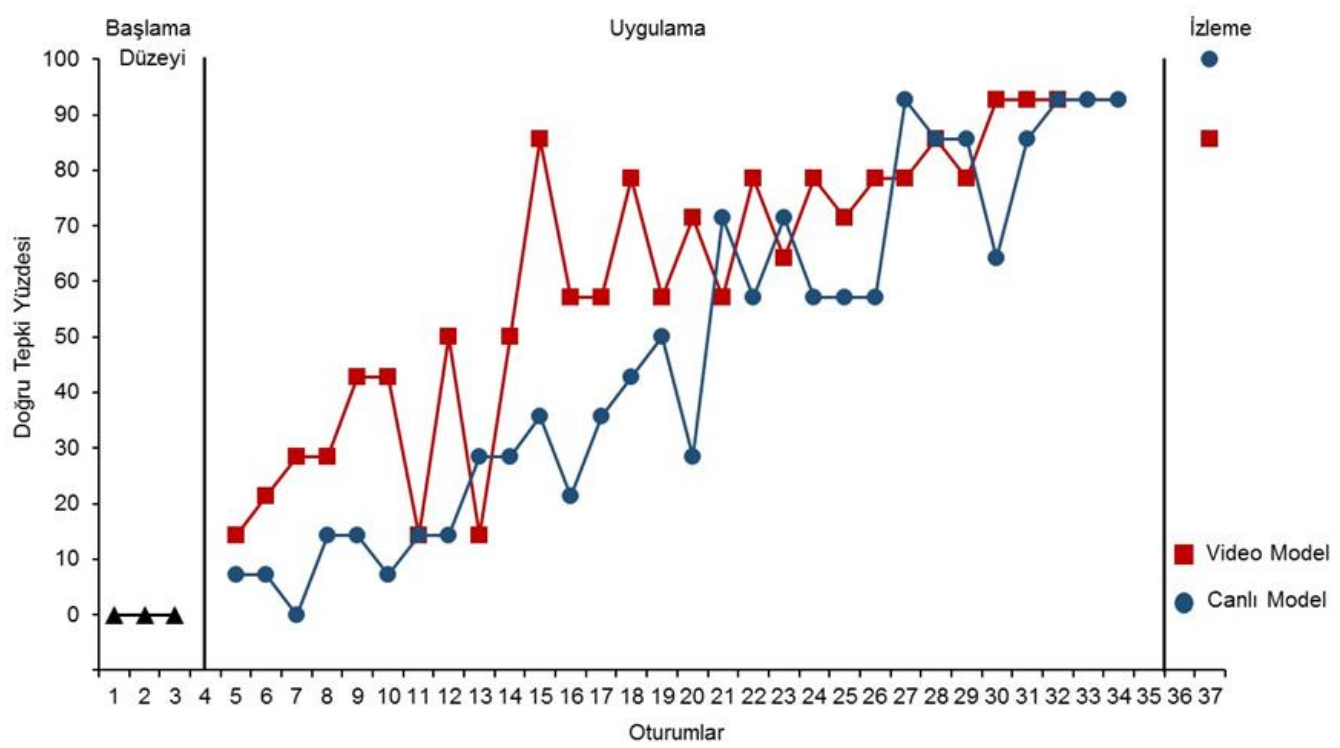

Salih'in sembolik oyun becerilerine ilişkin başlama düzeyi, uygulama ve izleme evrelerinde elde edilen veriler Şekil 2'de gösterilmektedir. Şekil 2'de de görüldüğü gibi Salih'in başlama düzeyi evresinde hem garsonluk hem de berberlik oyununa ilişkin performans düzeyi \%0'dır. Salih'in uygulama evresinde her iki oyunda da ilerleme sergilediği ve ölçütü karşılayarak \%85 düzeyinde doğru tepkide bulunduğu; izleme evresinde ise garsonluk oyununu \%100, berberlik oyununu \%85.7 düzeyinde koruduğu görülmektedir.

Salih; canlı modelle öğretimin sunulduğu 28 öğretim oturumu sonunda garsonluk oyununda, video modelle öğretimin sunulduğu 24 öğretim oturumu sonunda berberlik oyununda üç oturum ard arda \%85 ve üzerinde performans sergileyerek ölçütü karşılamıştır; ancak ölçüt için grup performansı dikkate alındığından tüm katılımcılar ölçütü karşılayıncaya değin öğretime devam edilmiştir. İşlevsel ilişkinin büyüklüğünü belirlemek üzere gerçekleştirilen OAVY hesaplaması sonucu canlı model için \% 79 , video model için \%96 bulunmuştur.

\section{Şekil 2}

Salih 'in Başlama Düzeyi, Uygulama ve İzleme Evrelerinde Berberlik ve Garsonluk Oyunlarına İlişkin Doğru Tepki Yüzdeleri

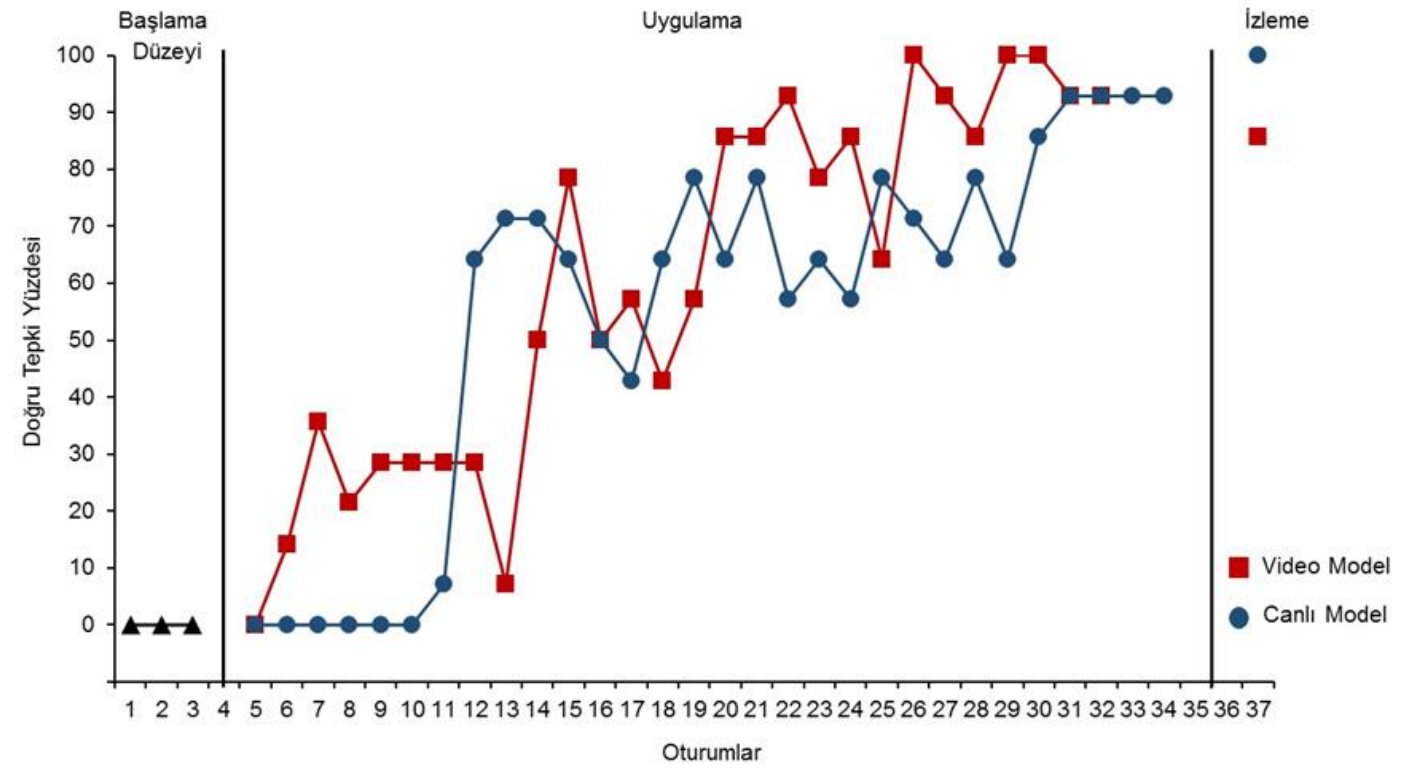


Selim'in sembolik oyun becerilerine ilişkin başlama düzeyi, uygulama ve izleme evrelerinde elde edilen veriler Şekil 3 'te gösterilmektedir. Şekil 3'te de görüldüğü gibi Selim'in başlama düzeyi evresinde hem garsonluk hem de berberlik oyununa ilişkin performans düzeyi \%0'dır. Selim'in uygulama evresinde her iki oyunda da ilerleme sergilediği ve ölçütü karş1layarak \%85 düzeyinde doğru tepkide bulunduğu; izleme evresinde ise garsonluk oyununu \%100, berberlik oyununu \%88.8 düzeyinde koruduğu görülmektedir.

Selim; canlı modelle öğretimin sunulduğu 29 öğretim oturumu sonunda garsonluk oyununda, video modelle öğretimin sunulduğu 18 öğretim oturumu sonunda berberlik oyununda üç oturum art arda \% 85 ve üzerinde performans sergileyerek ölçütü karşılamıştır. İşlevsel ilişkinin büyüklüğünü belirlemek üzere gerçekleştirilen OAVY hesaplaması sonucu canlı model için \%80, video model için \%100 bulunmuştur.

\section{Şekil 3}

Selim 'in Başlama Düzeyi, Uygulama ve İzleme Evrelerinde Berberlik ve Garsonluk Oyunlarına İlişkin Doğru Tepki Yüzdeleri

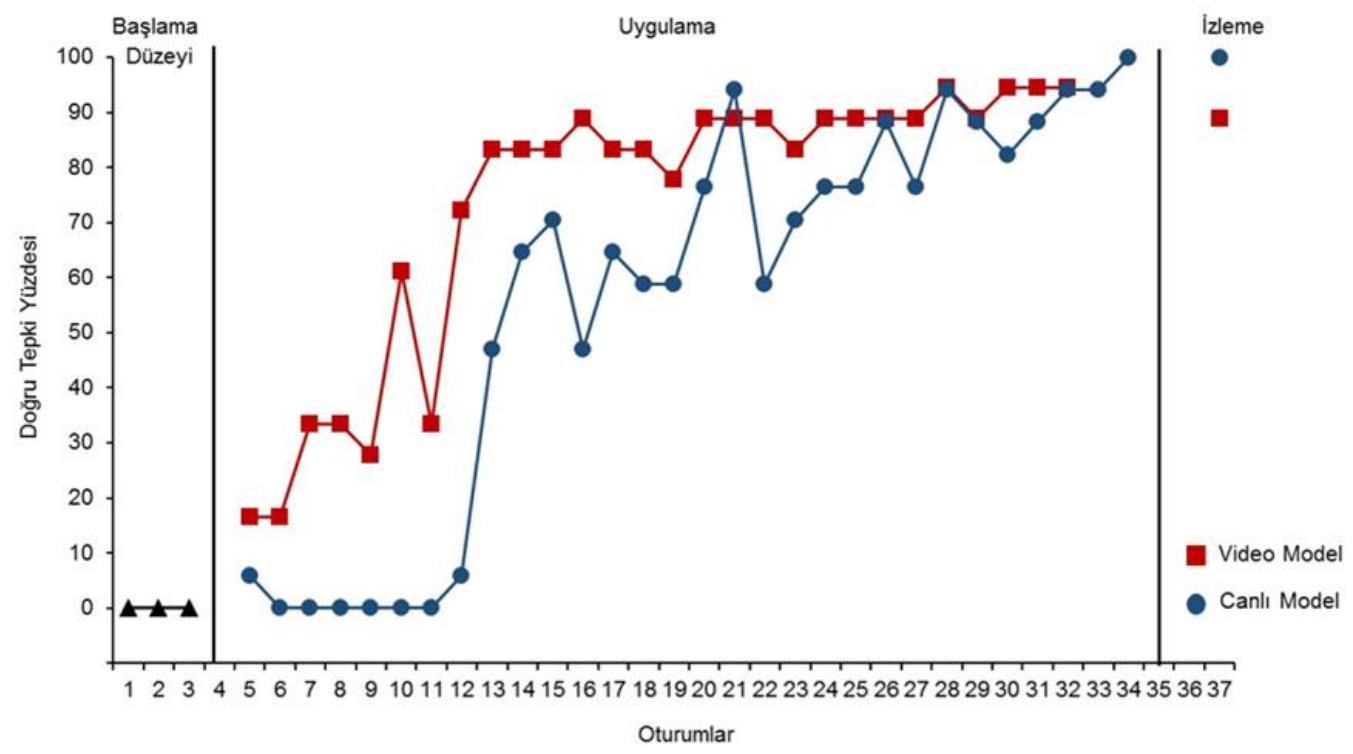

Kaan, Salih ve Selim'in berberlik ve garsonluk oyunları için genelleme ön test ve genelleme son test oturumlarında sergiledikleri doğru tepkilere ilişkin bulgularda; Kaan genelleme ön test oturumunda hem garsonluk hem berberlik oyununa ilişkin doğru tepki sergilemezken; genelleme son test oturumunda her iki oyuna ilişkin de \%85.7 doğru tepki göstererek oyunları farklı kişilere ve araç-gereçlere genellemiştir. Salih genelleme öntest oturumunda hem garsonluk hem berberlik oyununa ilişkin doğru tepki sergilemezken; genelleme son test oturumunda garsonluk oyununa ilişkin \%85.7, berberlik oyununa ilişkin \%92.8 doğru tepki göstererek oyunları farklı kişilere ve araç-gereçlere genellemiştir. Selim genelleme öntest oturumunda garsonluk oyununa ilişkin \%5.8, berberlik oyununa ilişkin \%5.5 doğru tepki sergilerken; genelleme sontest oturumunda garsonluk oyununa ilişkin $\% 100$, berberlik oyununa ilişkin \%88.8 doğru tepki göstererek oyunları farklı kişilere ve araç-gereçlere genellemiştir.

\section{Verimlilik Bulguları}

Sembolik oyunların öğretiminde küçük grup öğretimi biçiminde sunulan canlı modelle öğretim ile video modelle öğretimi verimlilik açısından karşılaştırılmak üzere ölçüt karşılanıncaya değin gerçekleşen; deneme sayısı, oturum sayısı, hata sayısı ve toplam öğretim süresi belirlenmiştir. Tablo 3 'te tüm denekler için her iki oyunda da ölçüt karşılanıncaya değin gerçekleşen; deneme sayısı, oturum sayısı, hata sayısı ve toplam öğretim süresine ilişkin veriler yer almaktadır. Tablo 3'te yer alan verilere göre; canlı modelle öğretim ile video modelle öğretim arasında iki denekte video modelle öğretim lehine, bir denekte ise canlı modelle öğretim lehine verimlilik açısından farklılık olduğunu göstermektedir. 
Tablo 3

Küçük Grup Öğretimi Biçiminde Sunulan Canlı Modelle Öğretim ile Video Modelle Öğretime İlişkin Verimlilik Verileri

\begin{tabular}{ccccccc}
\hline \multirow{2}{*}{ Denek } & $\begin{array}{c}\text { Bağımsız } \\
\text { değişken }\end{array}$ & Bağımlı değişken & $\begin{array}{c}\text { Deneme } \\
\text { sayısı }\end{array}$ & $\begin{array}{c}\text { Oturum } \\
\text { sayısı }\end{array}$ & $\begin{array}{c}\text { Hata } \\
\text { sayısı }\end{array}$ & $\begin{array}{c}\text { Toplam süre } \\
\text { öğretim + yoklama = sa:dk:sn }\end{array}$ \\
\hline \multirow{2}{*}{ Kaan } & Canlı model & Garsonluk oyunu & 30 & 30 & 133 & $56: 26+61: 10=1: 57: 36$ \\
& Video model & Berberlik oyunu & 28 & 28 & 155 & $91: 21+61: 18=2: 32: 39$ \\
\multirow{3}{*}{ Salih } & Canlı model & Garsonluk oyunu & 28 & 28 & 179 & $51: 00+58: 00=1: 49: 00$ \\
& Video model & Berberlik oyunu & 24 & 24 & 133 & $64: 49+67: 28=2: 12: 17$ \\
\multirow{2}{*}{ Selim } & Canlı model & Garsonluk oyunu & 29 & 29 & 203 & $53: 00+59: 00=1: 52: 00$ \\
& Video model & Berberlik oyunu & 18 & 18 & 115 & $50: 28+53: 05=1: 43: 33$ \\
\hline
\end{tabular}

\section{Gözleyerek Öğrenme Bulguları}

Araştırmada sembolik oyunların öğretiminde küçük grup öğretimi biçiminde sunulan canlı modelle öğretim ile video modelle öğretimin etkililiklerinin ve verimliliklerinin yanı sıra, gözleyerek öğrenmenin gerçekleşip gerçekleşmediği de belirlenmeye çalışılmıştır. Gözleyerek öğrenmeye ilişkin bulgularda her bir denek için kendi rolü olmayan diğer iki rolü gözleyerek öğrenme verileri garsonluk ve berberlik oyunları için ayrı ayrı olacak biçimde açıklanmıştır.

Kaan'ın hem garson hem de müşteri rolüne ilişkin ön test oturumunda sergilediği performans düzeyi $\% 0$ 'dır. Kaan garson rolüne ilişkin gözleyerek öğrenme; 1. yoklama oturumunda $\% 72$, 2. yoklama oturumunda $\% 72$, 3. yoklama oturumunda $\% 78$ ve son test oturumunda $\% 85$ düzeyinde; müşteri rolüne ilişsin ise gözleyerek ögrenme, 1. yoklama oturumunda $\% 95,2$. yoklama oturumunda $\% 85,3$. yoklama oturumunda $\% 88$ ve son test oturumunda \%100 düzeyinde doğru tepkide bulunmuştur. Kaan'ın hem berber rolüne hem de çırak rolüne ilişkin ön test oturumunda sergilediği performans düzeyi \%0'dır. Kaan berber rolüne ilişkin gözleyerek öğrenme; 1 . yoklama oturumunda $\% 78,2$. yoklama oturumunda $\% 85,3$. yoklama oturumunda $\% 78$ ve son test oturumunda $\% 85$ düzeyinde; çırak rolüne ilişkin ise gözleyerek öğrenme, 1. yoklama oturumunda \%78, 2. yoklama oturumunda $\% 78,3$. yoklama oturumunda $\% 85$ ve son test oturumunda $\% 78$ düzeyinde doğru tepkide bulunmuştur.

Salih'in hem müdür hem de müşteri rolüne ilişkin ön test oturumunda sergilediği performans düzeyi $\% 0$ 'dır. Salih müdür rolüne ilişkin gözleyerek öğrenme, 1. yoklama oturumunda $\% 79$, 2. yoklama oturumunda $\% 79,3$. yoklama oturumunda $\% 85$ ve son test oturumunda $\% 85$ düzeyinde; müşteri rolüne ilişkin ise gözleyerek öğrenme, 1. yoklama oturumunda $\% 75,2$. yoklama oturumunda $\% 85,3$. yoklama oturumunda $\% 96$ ve son test oturumunda \%85 düzeyinde doğru tepkide bulunmuştur. Salih’in hem çırak hem de müşteri rolüne ilişkin ön test oturumunda sergilediği performans düzeyi \%0dır. Salih çırak rolüne ilişkin gözleyerek öğrenme; 1. yoklama oturumunda $\% 72$, 2. yoklama oturumunda $\% 78$, 3. yoklama oturumunda $\% 72$ ve son test oturumunda $\% 89$ düzeyinde; müşteri rolüne ilişkin ise gözleyerek öğrenme, 1. yoklama oturumunda $\% 75$, 2. yoklama oturumunda $\% 100,3$. yoklama oturumunda $\% 50$ ve son test oturumunda $\% 96$ düzeyinde doğru tepkide bulunmuştur.

Selim'in hem müdür hem de garson rolüne ilişkin ön test oturumunda sergilediği performans düzeyi $\% 0$ 'dır. Selim berber rolüne ilişkin gözleyerek öğrenme; 1 . yoklama oturumunda $\% 50$, 2. yoklama oturumunda $\% 71$, 3. yoklama oturumunda $\% 79$ ve son test oturumunda \%71 düzeyinde; müşteri rolüne ilişkin ise gözleyerek öğrenme, 1. yoklama oturumunda $\% 65,2$. yoklama oturumunda $\% 65,3$. yoklama oturumunda $\% 79$ ve son test oturumunda \%79 düzeyinde doğru tepkide bulunmuştur. Selim'in hem berber hem de müşteri rolüne ilişsin ön test oturumunda sergilediği performans düzeyi \%0'dır. Selim berber rolüne ilişkin gözleyerek öğrenme; 1 . yoklama oturumunda $\% 50,2$. yoklama oturumunda $\% 78,3$. yoklama oturumunda $\% 78$ ve son test oturumunda \%85 düzeyinde; müşteri rolüne ilişkin ise gözleyerek öğrenme, 1. yoklama oturumunda \%85, 2. yoklama oturumunda $\% 92,3$. yoklama oturumunda $\% 85$ ve son test oturumunda $\% 78$ düzeyinde doğru tepkide bulunmuştur.

\section{Sosyal Geçerlik Bulguları}

Araştırmada belirlenen amaçların, kullanılan yöntemin ve elde edilen sonuçların anlamlılığına ilişkin sosyal geçerlik verileri öznel değerlendirme yolu ile toplanmıştır. Öznel değerlendirme deneklerin kendilerinden ve OSB olan çocuklara yönelik dersler almış olan öğretmen adaylarından görüş alınarak gerçekleştirilmiştir. 
Deneklerle yapılan görüşmeler araştırmacının kendisi tarafından gerçekleştirilmiş ve bu görüşmeler video kaydı yoluyla kaydedilmiştir. Görüşmeler sırasında deneklere dört adet yapılandırılmış görüş̧e sorusu yöneltilmiştir. Birinci soruda deneklere "Bu çalışmaya katılmaktan mutlu musun?" sorusu sorulmuş ve deneklerin tümünden evet yanıtı alınmıştır. İkinci soruda deneklere, araştırmada kullanılan öğretim yöntemlerinin tercihine ilişkin olarak "Öğrendiğin oyunları bilgisayardan (video görüntüsünden) izlemek mi daha keyifli yoksa canlı modellerden izlemek mi daha keyifli?" sorusu yöneltilmiş ve deneklerin tümü bu soruyu bilgisayardan (video görüntüsünden) izlemeyi daha keyifli bulduklarını ifade ederek yanıtlamışlardır. Üçüncü soruda araştırmada öğretimi yapılan oyunların tercihine ilişkin olarak "Garsonluk ve berberlik oyunları arasından hangi oyunu oynamayı daha çok seviyorsun?" sorusu sorulmuş ve bu soruda deneklerden ikisi berberlik oyununu, biri ise garsonluk oyununu oynamayı daha çok sevdiklerini dile getirmişlerdir. Dördüncü soruda deneklere "Bir daha böyle bir çalışmada yer almak ister misin?" sorusu yöneltilmiş ve deneklerin tümü bir daha böyle bir çalışma gerçekleştirildiğinde çalışmada yer almak istediklerini ifade ederek yanıtlamışlardır.

Araştırmada deneklerin kendilerinin yanı sıra OSB olan çocuklara yönelik çeşitli dersler almış, ve Öğretmenlik Uygulaması I dersini tamamlamış, olan öğretmen adaylarından da araştırmada belirlenen amaçların önemine, kullanılan yöntemin uygunluğuna ve elde edilen sonuçların anlamlılı̆̆ına ilişkin sosyal geçerlik verileri toplanmıştır. Araştırmada sosyal geçerlik soru formlarının nasıl doldurulacağı açıklandıktan sonra öğretmen adaylarına canlı modelle öğretime ve video modelle öğretime ilişkin başlama düzeyi oturumları, öğretim oturumları ve doğal yoklama oturumlarına ait görüntüler izletilmiş, ve katılım için gönüllü olan öğretmen adaylarından sosyal geçerlik soru formunda yer alan soruları yanıtlamaları istenmiştir. Öğretmen adaylarından dokuz soruyu yanıtlamaları beklenmiştir. OSB olan çocuklar için sembolik oyun öğretimini önemli bulduklarını, küçük grup öğretiminin OSB olan çocuklar için uygun ve avantajlı olduğunu, sembolik oyunların öğretiminde hem canlı modelle öğretimin hem de video modelle öğretimin etkili göründüğünü, kullanım açısından çoğunlukla canlı modelle öğretimi tercih ettiklerini ve çalışmayı büyük ölçüde beğendiklerini ifade etmişlerdir.

\section{Tartışma}

Araştırma bulguları, küçük grup öğretimi biçiminde sunulan canlı modelle öğretim ve video modelle öğretimin OSB olan çocuklara sembolik oyunların kazandırılmasında, kazanılan sembolik oyunların öğretim sona erdikten sonra da korunmasında, farklı araç gereçlere ve kişilere genellenmesinde etkili olduğunu göstermektedir. Araştırmanın bulguları sembolik oyunların edinim aşamasında küçük grup öğretimi biçiminde sunulan video modelle öğretimin, canlı modelle öğretime kıyasla daha etkili olduğunu ortaya koymaktadır. Bulgular ayrıca, canlı modelle öğretim ile video modelle öğretim arasında iki denekte video modelle öğretim lehine, bir denekte ise canlı modelle öğretim lehine verimlilik açısından farklılık olduğunu göstermektedir. Araştırmanın bulgularında kalıcılık aşamasında ise canlı modelle öğretimin video modelle öğretime kıyasla daha etkili olduğu; genelleme aşamasında ise canlı modelle öğretim ve video modelle öğretim arasında fark olmadığı görülmüştür.

Araştırma bulguları, OSB olan çocuklara sembolik oyunların kazandırılmasında küçük grup öğretimi biçiminde sunulan canlı modelle öğretim ve video modelle öğretimin her ikisinin de etkili olduğunu göstermektedir. Bu bulgu, OSB olan çocuklara oyun becerilerinin öğretilmesinde hem canlı modelle öğretimin hem de video modelle öğretimin etkili olduğunu ortaya koyan önceki araştırma bulguları ile tutarlılık göstermektedir. (Boudreau \& D'Entremont, 2010; D'Ateno vd., 2003; Jahr vd., 2000; MacDonald vd., 2005; Özen vd., 2012; Paterson \& Arco, 2007; Reagon vd., 2006; Tryon \& Keane, 1986). Yapılan bu araştırmada canlı modelle öğretim ile video modelle öğretim etkililikleri açısından karşılaştırıldıklarında elde edilen bulgular, çok büyük farkla olmasa da tüm denekler için video modelle öğretimin canlı modelle öğretime kıyasla daha etkili olduğunu gösterir niteliktedir. Bu bulgu, her iki öğretim uygulamasının etkililiklerini karşılaştırmak üzere gerçekleştirilen OAVY hesaplamaları ile de desteklenmektedir. Ma (2009) tarafından önerilen ölçütler dikkate alınarak yorumlandığında, tüm denekler için canlı modelle öğretim orta düzeyde; video modelle öğretimin yüksek düzeyde etkili olduğu görülmektedir. Bu bulgu, OSB olan çocuklara oyun oynamanın öğretiminde video modelle öğretimin canlı modelle öğretime göre daha hızlı bir edinim sağladığını ortaya koyan bir araştırma ile benzerlik gösterirken (Charlop-Christy vd., 2000); canlı modelle öğretim ile video modelle öğretimin eşit derecede etkili olduğunu ortaya koyan diğer araştırma bulgularından farklılaşmaktadır (Ergenekon vd., 2014; Gena vd., 2005; Odluyurt, 2013). Araştırmada özellikle iki denekte (Salih ve Selim) video modelle öğretimin kullanıldığ berberlik oyununun düzeyinde ilk üç öğretim oturumunda önemli bir değişiklik olurken, canlı modelle öğretimin kullanıldı̆̆ garsonluk oyununun düzeyinde ancak 7-8 öğretim oturumunun sonunda değişiklik olmuştur. Bu durum, araştırmadaki genel gözlemlere dayalı olarak deneklerin canlı modelle öğretimde sergilenen performanslar ile video modelle öğretim görüntüsünü farklı biçimde izlemeleri ile açıklanabilir. Yapılan gözlemlerde deneklerin video modelle öğretim sırasında dikkatlerini video görüntüsünün tümüne yönelttikleri; ancak canlı modelle öğretim sırasında dikkatlerini 
yalnızca kendi rollerine ilişkin performans sergileyen modele yönelttikleri dikkat çekmiştir. Canlı modelle öğretim, pek çok davranışın kazandırılmasında etkili olduğu ve çocuklara doğrudan ve somut bir model sağladığı için oldukça avantajlı bir öğretim uygulamasıdır; ancak her öğretim oturumunda hedef davranışı gerçekleştirmek üzere gerekli olan ortamı düzenlemek, modelin ya da modellerin ortamda hazır bulunmalarını sağlamak ve modelin ya da modellerin kazandırılması hedeflenen davranışı her seferinde aynı biçimde sergilemelerini kesinleştirmek zor olduğu için canlı modelle öğretimin kullanımı zorlaşmaktadır (Jahr vd., 2000; Tryon \& Keane, 1986). Video modelle öğretim ise, yüksek nitelikli video görüntülerinin hazırlanması zor olduğu ve öğretim sırasında teknolojik donanım gerektirdiği için uygulamacılar açısından zor olsa da video görüntüsü oluşturulduktan sonra defalarca izlemeye olanak sağlaması, çocukların video görüntülerini izlemekten keyif almaları ve kullanımının kolay olması açısından uygulamacılar tarafından tercih edilmektedir (Ayres \& Langone, 2005; Ergenekon vd., 2014; Graetz vd., 2006). Bu araştırmada, her iki öğretim uygulamasına ilişkin yukarıda sıralanan avantajlar ve dezavantajların yanı sıra ekonomik olması, hazırlık için daha az zaman gerektirmesi ve kullanımının kolay olması, tekrar tekrar izlenebilmesi ve izlerken durdurulabilmesi gibi özellikleri nedeniyle canlı modelle öğretime kıyasla video modelle öğretimin daha etkili olabildiği düşünülmektedir.

Araştırmada deneysel kontrolü sağlamak üzere araştırma süresince canlı modelle öğretim ve video modelle öğretime ek olarak ipucu, dönüt ve pekiştirme kullanılmamıştır. Modelle öğretimin kullanıldığı araştırmalarda sıklıkla tartışılan konulardan birisi modelle öğretime ek olarak ipucu, dönüt ve pekiştirme gibi düzenlemeler kullanıldığında (Ergenekon vd., 2014; Odluyurt, 2013; Özen vd., 2012) etkililik bulgularının modelle öğretimden mi yoksa modelle öğretime ek olarak kullanılan ipucu, dönüt ve pekiştirmeden mi kaynaklandığının kesin biçimde ayırt edilememesidir (Allen vd., 2010; Bellini \& Akullian, 2007). Dolayısıyla, daha önce gerçekleştirilen bazı araştırmalarda (Allen vd., 2010; Charlop vd., 2010; D’Ateno vd., 2003) olduğu gibi bu araştırmada da canlı modelle öğretim ve video modelle öğretime ek olarak ipucu, dönüt ya da pekiştirme kullanılmamasının araştırmanın iç geçerliğini arttırdığı ve bu araştırmayı güçlü kılarak mevcut alanyazına katkı sağladığı düşünülmektedir. Ancak bu durum araştırmanın iç geçerliğine katkıda bulunmasına karşın zaman zaman deneklerin ve araştırmacının zor anlar yaşamalarına neden olmuştur. Denekler, özellikle doğal yoklama oturumlarında sergiledikleri performanslara ilişkin araştırmacından dönüt ya da pekiştirme beklemişler ve sıklıkla bu konudaki beklentilerini dile getirmişlerdir. Oyun oynamak denekler için doğal pekiştireç özelliği taşımamış bu süreci daha çok bir iş/görev gibi geçirmişlerdir. Dolayısı ile oturum sonlanır sonlanmaz zaman zaman da kamera kapanır kapanmaz araştırmacı tarafından coşkulu biçimde sosyal pekiştireçlerle pekiştirilmeyi beklemişlerdir.

Araştırmanın etkililik bulgularından yola çıkılarak, OSB olan çocukların sembolik oyunları video modelle ve canlı modelle öğretim sunularak öğrenebildikleri ifade edilebilir. Bu bulguları desteklemek üzere öğretmen adaylarından toplanan sosyal geçerlik verilerinin olumlu yönde olduğu göze çarpmış ve öğretmen adayları OSB olan çocukların sosyal gelişiminde, yeni ve farklı davranış öğretiminde, hayal gücünü geliştirmesinde ve oyun oynamayı öğrenmesinde sembolik oyunun büyük ölçüde katkı sağladığını ifade etmeleri de ortaya çıkan bulguları destekler nitelikte olduğu görülmüştür (Boutot vd., 2005; Paterson \& Arco, 2007; Reagon vd., 2006).

$\mathrm{Bu}$ araştırmada hem video model hem de canlı model uygulaması OSB tanısı almış öğrencilerin bir araya gelmesinden oluşan küçük grup öğretimi düzenlemesiyle yapılmıştır. OSB olan çocuklarla küçük grup düzenlemesiyle yapılan öğretimlerin etkililiğini ortaya koyan çalışma sonuçlarıyla yapılan bu çalışmanın sonuçlarının örtüşstüğü görülmüşsür (Fickel vd., 1998). Sözü edilen bu çalışmalarda özbakım, okuma yazmaya ilişkin davranışlar gibi akademik davranışlar çalışılmıştır. Özen ve diğerlerinin (2012) gerçekleştirdikleri çalışmada da küçük grup düzenlemesi ile sunulan sembolik oyun öğretimin etkili olduğu gözlenmiştir. Küçük grup öğretimine ilişkin düzenlemenin yapılmasını ön gören çalışmalar yapılmasına rağmen bu çalışmaların çok sayıda olmadığı bilinmektedir. Küçük grup öğretimi ile gerçekleşen düzenlemenin birebir öğretim düzenlemesine kıyasla avantajları hem denekler hem de uygulamacılar açısından tartışılabilir. Denekler açısından; deneklerin farklı ortamlarda yer almasını, grupta yer alan akranları ile iletişime girmelerini ve iş birliği yapmalarını ve grup içinde birbirlerinin davranışlarını gözleyerek öğrenmelerini sağlaması nedeni ile birebir bir öğretim düzenlemesine kıyasla üstün yönleri vardır. Uygulamacı ve araştırmacılar açısından ise, denekler için belirlenen hedef davranışları ayrı ayrı öğretmeye gerek kalmaması araştırmacı açısından oldukça önemli bir avantajdır. Bu araştırmada kullanılan küçük grup öğretimi biçiminde düzenlemede sözü edilen bu avantajlar göz önünde bulundurulmuş ve öğretmen adaylarının büyük çoğunluğu küçük grup öğretimi biçiminde yapılan düzenlemeyi başarılı ve sistematik bir uygulama olarak ifadeleri bu düzenlemenin üstün yanlarını ve araştırmayı güçlü kılmıştır.

Araştırma bulguları, OSB olan çocuklara sembolik oyunların kazandırılmasında küçük grup öğretimi biçiminde sunulan canlı modelle öğretim ve video modelle öğretimin sembolik oyunların kazanılmasının yanı sıra, 
kazanılan oyunların öğretim sona erdikten 10 gün sonra korunmasında ve farklı araç gereçlere ve kişilere genellenmesinde etkili olduğunu göstermektedir. $\mathrm{Bu}$ bulgu, OSB olan çocuklara çeşitli oyunların kazandırılmasında canlı modelle öğretim ile video modelle öğretimin kalıcılık ve genelleme açısından etkili olduğunu gösteren önceki araştırma bulguları ile benzerlik göstermektedir (Boudreau \& D'Entremont, 2010; Jahr vd., 2000; MacDonald vd., 2009; Paterson \& Arco, 2007; Reagon vd., 2006; Tryon \& Keane, 1986). Araştırmanın bulguları, edinim aşamasında video modelle öğretimin canlı modelle öğretime kıyasla daha etkili olduğunu gösterse de kalıcılık ve genelleme aşamalarında bu durum farklılaşmaktadır. Bulgular, tüm denekler için kalıcılık aşamasında canlı modelle öğretimin video modelle öğretime kıyasla daha etkili olduğunu genelleme aşamasında ise canlı modelle öğretim ile video modelle öğretim arasında fark olmadığını göstermektedir. Bu araştırmada kalıcılığa ilişkin elde edilen bulgular OSB olan çocuklara oyun oynamanın öğretiminde video modelle öğretim ile canlı modelle öğretimin kalıcılık açısından farklılaşmadığını gösteren araştırmaların bulgularından (Ergenekon vd., 2014; Gena vd., 2005; Odluyurt, 2013) farklılık gösterse de genellemeye ilişkin elde edilen bulgular söz konusu araştırmaların bulguları ile tutarlıdır. Her ne kadar bulgular, tüm denekler için kalıcılık aşamasında canlı modelle öğretimin video modelle öğretime kıyasla daha etkili olduğunu gösterse de izleme evresinde yalnızca bir kez veri toplanmış olması bu bulgunun yeterince desteklenmesini engellemektedir. Araştırmada kazanılan oyunların öğretim sona erdikten sonra da korunup korunmadığını belirlemek üzere izleme oturumları planlanmış, izleme oturumlarının öğretim sona erdikten 10,60 ve 90 gün sonra gerçekleştirilmesi kararı alınmasına rağmen, araştırmada öğretim sona erdikten 10 gün sonra gerçekleştirilecek olan izleme oturumu eğitim öğretim döneminin bitmesine yakın gerçekleştirilmiş; ancak bir sonraki izleme tarihinde deneklerden birinin okul değiştirmiş olması ve kişisel nedenlerden dolayı okul saatleri dışında çalışmaya katılamaması sebebiyle bir kez izleme oturumu yapılabilmişsir.

Canlı modelle öğretim ile video modelle öğretim verimlilik açısından karşılaştırıldığında, elde edilen bulgular değişkenlik göstermektedir. Verimliliğe iliş̧in elde edilen bu bulgu, iki öğretim uygulaması arasında verimlilik açısından değişkenliğin bulunduğu önceki araştırmalarla benzerlik göstermektedir (Ergenekon vd., 2014; Odluyurt, 2013). Bulgulara göre ölçüt karşılanıncaya değin gerçekleşen oturum sayısı ve deneme sayısı açısından video modelle öğretimin üç denekte de daha verimli olduğu dikkati çekmektedir. Video modelle öğretim canlı modelle öğretime kıyasla daha verimli görünmektedir; ancak iki denekte oturum sayısı ve deneme sayısı arasındaki fark azken, bir denekte (Selim) bu farkın oldukça fazla olduğu göze çarpmaktadır. Elde edilen bulgular ölçüt karşılanıncaya değin gerçekleşen; hata sayısı açısından iki denekte (Salih ve Selim) video modelle öğretimin, bir denekte ise canlı modelle öğretimin (Kaan) daha verimli olduğunu göstermekte iken; toplam öğretim süresi açısından iki denekte (Kaan ve Salih) canlı modelle öğretimin daha verimli olduğunu, bir denekte (Selim) ise iki öğretim uygulamasının eşit derecede verimli olduğunu ortaya koymaktadır. Bu bulgu, Charlop-Christy ve diğerleri (2000) tarafından gerçekleştirilen ve toplam öğretim süresi açısından video modelle öğretimin daha verimli bulunduğu araştırmanın bulgularından farklılaşmaktadır. Araştırmada küçük grup öğretimi kullanılmış olması nedeniyle bazı deneklerde ölçüt karşılanmasına rağmen öğretime devam edilmiştir. Araştırmada deneklere, senaryosu üç farklı rolden oluşan sembolik oyunların kazandırılması hedeflenmiş, öğretim küçük grup öğretimi biçiminde gerçekleştirilmiş ve öğretimin sonlandırılması için üç denekte de ölçütün karşılanmış olması gerekmiş̧tir. Araştırmada verimlilik bulguları sunulurken her bir deneğin kendi rolünde ölçüte ulaş̧ı̆̆ zamandaki sayılar ve süreler verilmiş olmasına karşın bir denekte ölçüt karşılansa da öğretime devam edildiğinden, aslında o denek için daha fazla sayıda ve sürede öğretim oturumu gerçekleştirilmiştir. Bu durum canlı modelle öğretim açısından denekler arasında önemli bir fark oluşturmazken, video modelle öğretim açısından Selim'de ciddi bir farkla sonuçlanmıştır. Ortaya çıkan bu tablo deneklere ait grafikler üzerinde de açıkça görülmektedir. Grafiklerde elde edilen veriler doğal yoklama oturumlarında toplanmıştır. Doğal yoklama oturumları canlı modelle öğretimin kullanıldığı garsonluk oyunu için ortalama 2 dk.'da tamamlanırken, video modelle öğretimin kullanıldığı berberlik oyunu için ortalama 3,5 dk.'da tamamlanmıştır. Öğretim oturumlarının süresine doğal yoklama oturumlarının süresi eklendiğinde hem canlı modelle öğretimin hem de video modelle öğretimin toplam öğretim süreleri en az iki katına çıkarak önemli ölçüde artmıştır.

Bireyler her zaman öğrenecekleri bilgi, beceri ya da davranış üzerinde doğrudan çalışma ya da deneyim elde etme olmadan, diğer bireylere bu davranışlar öğretilirken ya da diğer bireyler bu davranışları sergilerken gözleyerek de öğrenebilirler. Bu araştırmada, her bir denekten garsonluk ve berberlik olmak üzere iki farklı oyunda kendileri için belirlenmiş olan birer role ilişkin replik ve davranışları kazanarak yerine getirmeleri beklenmiş; ancak deneklerin akranlarının rolleri olan diğer iki rolü de gözleyerek öğrenme aracıllğıyla öğrenip öğrenmedikleri sınanmıştır. Gözleyerek öğrenmeye ilişkin yapılan sınamada deneklerin tümünün her iki oyunda da diğer iki rolü \%70 ve üzerinde performans sergileyerek gerçekleştirdikleri gözlenmiştir. Buna göre, araştırmada deneklerden her iki oyuna ilişkin birer rol olmak üzere iki rolü sergilemeleri beklenirken, denekler her oyunda ikişer farklı rol 
daha olmak üzere toplam altı rolü de yerine getirmişlerdir. OSB olan çocukların taklide yönelik etkinlikleri gerçekleştirmede ve öğretim süreci içinde var olan modeli izlemeye yönelik sınılıkları vardır. Araştırma bulguları, hem garsonluk oyununun öğretildiği canlı modelle öğretimde hem de berberlik oyununun öğretildiği video modelle öğretimde tüm deneklerin kendi rolleri dışındaki diğer iki rolü de oyun içindeki akranlarını gözleyerek öğrendiklerini gösterir niteliktedir. Bu bulgu, Özen ve diğerleri (2012) tarafindan OSB olan çocuklara sembolik oyunların öğretiminde küçük grup öğretimi biçiminde sunulan video modelle öğretim sırasında gözleyerek öğrenmenin gerçekleştiğini ortaya koyan araştırmanın bulguları ile paralellik göstermektedir. Araştırmada deneklerin oynadıkları oyun içinde yer alan diğer iki rolü akranlarını gözleyerek öğrendikleri varsayılsa da bu öğrenmenin, deneklerin öğretim oturumlarında video modelle öğretim ve canlı modelle öğretim sonucu mu, yoksa yoklama oturumlarında akranlarını gözlemeleri sonucu mu gerçekleştiği tam olarak ayırt edilememektedir. Araştırmada elde edilen gözleyerek öğrenme bulguları bu durum dikkate alınarak yorumlanmalıdır.

Araştırmada sosyal geçerlik verileri farklı kaynaklardan toplanmıştır. Bir araştırmanın sosyal geçerliğinin değerlendirilmiş olması o çalışmanın başarısının önemli ölçütlerinden biri olarak kabul edilmektedir (Schwartz \& Baer, 1991; Vuran \& Sönmez, 2008). Bu araştırmada hem belirlenen amaçların önemine hem kullanılan yöntemin uygunluğuna hem de elde edilen sonuçların anlamlılı̆̆ına ilişkin görüşlerini belirlemek üzere deneklerden ve öğretmen adaylarından sosyal geçerlik verileri toplanmıştır. Alanyazında, araştırmanın dolaylı kullanıcılarının yanı sıra doğrudan kullanıcılarından da sosyal geçerlik verisi toplanması nedeni ile (Schwartz \& Baer, 1991) araştırmanın alanyazına katkı sağladığını söylemek mümkündür.

Araştırma bulguları, araştırmaya katılan deneklerin ve öğretmen adaylarının araştırmaya ilişkin görüşlerinin olumlu olduğunu göstermektedir. Kendileriyle görüşülen deneklerin tümü çalışmaya katılmaktan memnun olduklarını ve ileride yeniden böyle bir çalışmaya katılabileceklerini söylemişler, kullanılan öğretim uygulamalarından video modelle öğretimi daha fazla tercih ettiklerini ifade etmişler, deneklerden ikisi berberlik, biri ise garsonluk oyununu daha keyifli bulduklarını dile getirmişlerdir. Berberlik oyununu daha keyifli bulan deneklerin her ikisi de berberlikte kullanılan araçlara ve de gerçekleştirilen davranışlara ilgilerinin garsonluk oyununa kıyasla biraz daha üst düzeyde olmasına yordanabilir. Çünkü her öğretim oturumu için bir araya gelindiğinde deneklerden ikisi berberlik oyununu ne zaman oynayacă̆ız diye sormuş ya da sıradaki oyun garsonluk oyunu ise berberlik oyununu oynayalım ifadesini dile getirmiş olmaları berberlik oyununu daha çok tercih ettiklerini açıklayabilir. Ancak deneklerden birisi berberlik oyununu video modelle öğretimle daha hızlı öğrenmesine rağmen garsonluk oyununun basamaklarını tamamlamada daha hızlı olduğu için bu durum onu motive etmiş ve garsonluk oyununu daha çok sevdiğini söylemiş̧ir.

Araştırmaya ilişkin görüşleri belirlenen öğretmen adayları ise; OSB olan çocuklar için sembolik oyun öğretimini önemli bulduklarını, küçük grup öğretiminin OSB olan çocuklar için uygun ve avantajlı olduğunu, sembolik oyunların öğretiminde hem canlı modelle öğretimin hem de video modelle öğretimin etkili göründüğünü, kullanım açısından çoğunlukla canlı modelle öğretimi tercih ettiklerini ve çalışmayı büyük ölçüde beğendiklerini ifade etmişlerdir. Hem deneklerin hem de öğretmen adaylarının görüşlerini yansıtan bu bulgu, deneklerin ailelerinden ve akranlarından sosyal geçerlik verilerinin toplandığı önceki araştırmaların bulguları ile benzerdir (Ergenekon vd., 2014; Odluyurt, 2013). Araştırmada elde edilen sosyal geçerlik bulgularına dayalı olarak araştırmanın sosyal geçerliğinin yüksek olduğunu söylemek mümkündür.

Araştırmanın güçlü yanlarının yanında bazı sınırlılıkları da bulunmaktadır. Araştırmaya ilişkin önemli bir sınırlılık, video modelle öğretim ile canlı modelle öğretimde kullanılan modellerin farklılaşmasııdır. Araştırmada, alanyazındaki bilgiler dikkate alınarak hem video modelle öğretimde hem de canlı modelle öğretimde kullanılan modellerin deneklerin cinsiyetleri ile aynı cinsiyette (erkek) olmalarına ve modellerin fiziksel özellikler açısından birbirlerine benzemelerine özellikle dikkat edilmiştir. Planlama açısından yaşanan güçlükler nedeniyle, canlı modelle öğretimde kullanılan modeller ile video modelle öğretimde kullanılan modeller farklılık göstermiştir. Ayrıca canlı modelle öğretimde kullanılan modellerin deneklerin tanıdığı kişilerden olmasına karşın, video modelle öğretimde kullanılan modellerin deneklerin tanımadı̆̆ kişilerden olması araştırmanın önemli bir sınırlılığ olarak ifade edilebilir.

Araştırmanın bir diğer sınırlılı̆̆ı, araştırmadaki oyunlarda kullanılan araç gereçlerin büyük bir kısmının oyuncaklardan ya da farklı işlevlere hizmet eden nesnelerden oluşması, küçük bir bölümünün de gerçek nesnelerden oluşmasıdır. Sembolik oyunlarda gerçek nesnelerin kendi işlevleri dışında kullanılması söz konusudur; ancak bu araştırmada birkaç nesne kendi işlevinde kullanılmıştır. Az da olsa araştırmada nesnelerin kendi işlevlerinde kullanılmış olmaları sembolik oyunun doğasına çok uygun olmadığından bir sınırlılık olarak kabul edilebilir (gerçek ayna, firça, gerçek para ancak diğerleri oyuncak makas, tarak, şampuan, pizza vb.). 
Araştırmada canlı modelle öğretim ile video modelle öğretimi karşılaştırmak üzere uyarlamalı dönüşümlü uygulamalar modeli kullanılmıştır. Bu modelde her bir deneğe iki farklı bağımlı değişken kazandırılması hedeflenir ve bu bağımlı değişkenlerin eşit zorluk düzeyinde olması beklenir. Bu araştırmada, kazandırılması hedeflenen bağımlı değişkenlerin basamak sayıları ve gerektirdikleri davranışlar mantıksal analiz yapılarak eşitlenmeye çalışılmış ve bağımlı değişkenlerin eşit zorluk düzeyinde oldukları varsayılmıştır. Araştırmada bağımlı değişkenlerin eşit olup olmadıklarını belirlemek üzere deneysel analiz yapılmayıp yalnızca mantıksal analizin kullanılmış olması araştırmanın başka bir sınırlılığı olarak kabul edilebilir.

Araştırmanın son sınırlılığı ise, araştırmada kalıcılık verilerinin yalnızca bir oturum olmasıdır. Araştırmada kazanılan oyunların öğretim sona erdikten sonra da korunup korunmadığını belirlemek üzere izleme oturumları planlanmış, izleme oturumlarının öğretim sona erdikten 10, 60 ve 90 gün sonra gerçekleştirilmesi kararı alınmıştır. Araştırmada öğretim sona erdikten 10 gün sonra gerçekleştirilecek olan izleme oturumu eğitim öğretim döneminin bitmesine yakın gerçekleştirilmiş; ancak bir sonraki izleme tarihinde deneklerden birinin okul değiştirmiş olması ve kişisel nedenlerden dolayı okul saatleri dışında çalışmaya katılamaması sebebiyle planlanan izleme oturumları tamamlanamamıştır. Bu durum hem canlı modelle öğretimin hem de video modelle öğretimin kalıcılığının değerlendirilmesine ilişkin bir sınırlılık oluşturmaktadır.

Araştırmanın bulguları ve sınırlılıkları göz önünde bulundurularak ileri araştırmalara yönelik bazı önerilerde bulunulabilir. Video model öğretim ve canlı modelle öğretim sonrasında öğrenmenin olup olmadığını değerlendirebilmek denek performansının sürekli olarak izlenebilmesi amacıyla öğretim oturumlarından hemen sonra günlük yoklama oturumları düzenlenmiştir. Doğal yoklama oturumlarının düzenlenmesi uygulamacı için zaman ve maliyet açısından ek yük getirmekte ve öğretim sürecini zorlaştırması nedeniyle ileriki araştırmalarda ek yükü azaltmak ve öğretim sürecini kolaylaştırmak amacıyla günlük doğal yoklama oturumları yerine aralıklı doğal yoklama oturumları düzenlenebilir. Çalışmada canlı modelle öğretimde ve video modelle öğretimde model olan kişiler yetişkinlerdir. İleri araştırmalarda akranların model olması durumunda bu iki uygulamanın karşılaştırılması planlanabilir. Ayrıca hem video modelle öğretimde hem de canlı modelle öğretimde yer alan modellerin aynı kişilerden oluşması önerilebilir. Araştırmada kullanılan araç gereçlerin ya tümünün oyuncak ya da tümünün işlevi dışında gerçek nesnenin kullanılması önemlidir. İleriye dönük yapılacak araştırmalarda sembolik oyunun bir gereği olarak araştırmada yer alacak olan araç gereçlerin tümünün gerçek nesne kullanılacaksa gerçek nesnelerin işlevi dışında kullanılması ya da tümünün oyuncak olarak kullanılması önerilebilir. Araştırmada kullanılan modelin bir gerekliliği olarak her bir deneğe iki farklı bağımlı değişken kazandırılması hedeflenirken ve bu bağımlı değişkenlerin eşit zorluk düzeyinde olmasına dikkat edilir. Araştırmada bağımlı değişkenlerin eşit olup olmadıklarını belirlemek üzere deneysel analiz yapılamamasından yola çıkılarak bağımlı değişkenleri eşitlemek açısından mantıksal analiz yapılmıştır. İleri araştırmalara yönelik mantıksal analizin yanı sıra deneysel analiz yapılması diğer bir öneridir. Bu araştırmada yer alan sınırlılıklardan birisi de izleme verisinin planladığı zamanda yapılamamış olmasıdır. Araştırmada yer alan modelin bir gerekliliği olmamasına rağmen izleme verisi toplanması araştırmayı güçlü kılması açısından önemlidir. Bu nedenle izleme oturumlarının belirlenen sayıda ve birden fazla gerçekleştirilmesi önerilebilir. Araştırmada video modelle öğretimde kullanılan araç dizüstü bilgisayardır. İleri araştırmalarda dizüstü bilgisayar yerine tablet kullanılarak araştırma gerçekleştirilebilir. İleri araştırmalar açısından bulgular ele alındığında ise, öncelikle farklı düzeyde OSB olan çocuklara video modelle öğretim ve canlı modelle öğretim uygulamalarının karşılaştırılmasının planlandığı araştırmaların tasarlanması önerilebilir. İleri araştırmalar için bir diğer öneri ise, farklı davranışların öğretiminde bu iki öğretim uygulamasının karşılaştırılmasıdır (günlük yaşam becerileri, serbest zaman etkinlikleri, sosyal beceriler vb). Uygulamaya yönelik ise; OSB olan çocuklara sembolik oyunların öğretiminde öğretmenlere ve anne babalara video modelle öğretim surecini kullanmaları önerilmektedir. OSB olan çocukların sembolik oyunları öğrenebildikleri görülmüş, dolayısıyla anne babalara ve öğretmenlere farklı sembolik oyunların (doktorluk, öğretmenlik oyunları gibi) öğretimini farklı ortamlarda (evde, parkta) tercih edecekleri modelleme türlerinden birisi ile öğretmeleri önerilebilir.

\section{Yazarların Katkı Düzeyleri}

Çalışma iki yazar tarafından yürütülmüştür. İlk yazarın doktora tezidir. İkinci yazar ise tez danışmanıdır. Çalışma konusunu belirleme, araştırma deseni, veri toplama, verilerin analizi, çalışmanın raporlanması görevlerinde her iki yazar görev yapmıştır. 


\section{Kaynaklar}

Allen, K. D., Wallace, D. P., Renes, D., \& Bowen, S. L. (2010). Use of video modeling to teach vocational skills to adolescents and young adults with autism spectrum disorders. Education and Treatment of Children, 33(3), 339-349. https://doi.org/10.1353/etc.0.0101

Au, A., Mountjoy, T., Leaf, J. B., Leaf, R., Taubman, M., McEachin, J., \& Tsuji, K. (2016). Teaching social behaviour to individuals diagnosed with autism spectrum disorder using the cool versus not cool procedure in a small group instructional format. Journal of Intellectual and Developmental Disability, 41(2), 115-124. https://doi.org/10.3109/13668250.2016.1149799

Ayres, K. M., \& Langone, J. (2005). Intervention and instruction with video for students with autism: A review of the literature. Educating and Training in Developmental Disabilities, 40(2), 183-196. https://www.jstor.org/stable/23880090

Bandura, A., Ross, D., \& Ross, S. A. (1961). Transmission of aggression through imitation of aggressive model. Journal of Abnormal and Social Psychology, 63(3), 575-582. https://doi.org/10.1037/h0045925

Barton, E. E., \& Ledford, J. R. (2018). Effects of reinforcement on peer imitation in a small group play context. Journal of Early Intervention, 40(1), 69-86. https://doi.org/10.1177/1053815117748409

Bellini, S., Akullian, J., \& Hopf, A. (2007). A meta-analysis of video modeling and video self-modeling interventions for children and adolescents with autism spectrum disorders. Exceptional Children, 73(3), 264-287. https://doi.org/10.1177/001440290707300301

Benner, L. (2011). Comparing the effects of three modeling conditions on the performance of simple tasks by elementary aged children with autism spectrum disorders (Publication No. 3488033) [Doctoral dissertation, Indiana University]. ProQuest Dissertations and Theses Global.

Bernstorf, E. (2012). Parten's level of Kodaly Teaching. Kodaly Envoy, 39(1), 7-11.

Bernad-Ripoll, S. (2007). Using a self-as-model video combined with social stories to help a child with Asperger syndrome understand emotions. Focus on Autism and Other Developmental Disabilities, 22(2), 100-106. https://doi.org/10.1177/10883576070220020101

Boudreau, E., \& D’Entremont, B. (2010). Improving the pretend play skills of preschoolers with autism spectrum disorders: The effects of video modeling. Journal of Developmental Physical Disabilities, 22, 415-431. https://doi.org/10.1007/s10882-010-9201-5

Boutot, E. A., Guenther, T., \& Crozier, S. (2005). Let's play: Teaching play skills to young children with autism. Education and Training in Developmental Disabilities, 40(3), 285-292. https://www.jstor.org/stable/23879722

Carnahan, C., Musti-Rao, S., \& Bailey, J. (2009). Promoting active engagement in small group learning experiences for students with autism and significant learning needs. Education and treatment of Children, 32(1), 37-61. https://www.jstor.org/stable/42900006

Chai, Z. (2017). Improving early reading skills in young children through an iPad app: Small-group instruction and observational learning. Rural Special Education Quarterly, 36(2), 101-111. https://doi.org/10.1177/8756870517712491

Chang, Y. C., Shih, W., Landa, R., Kaiser, A., \& Kasari, C. (2018). Symbolic play in school-aged minimally verbal children with autism spectrum disorder. Journal of Autism and Developmental Disorders, 48(5), 14361445. https://doi.org/10.1007/s10803-017-3388-6

Charlop-Christy, M. H., \& Daneshvar, S. (2003). Using video modeling to teach perspective taking to children with autism. Journal of Positive Behavior Interventions, 5(1), 12-22. https://doi.org/10.1177/10983007030050010101

Charlop, M. H., Denis, B., Carpenter, M. H., \& Greenberg, H. (2010). Teaching socially expressive behaviors to children autism through video modeling. Education and Treatment of Children, 33(3), 371-393. https://doi.org/10.1353/etc.0.0104 
Charlop-Christy, M. H., Le, L., \& Freeman, K. A. (2000). A comparison of video modeling with in vivo modeling for teaching children with autism. Journal of Autism and Developmental Disorders, 30, 537-552. https://doi.org/10.1023/a:1005635326276

Collins, B. C., Gast, D. L., Ault, M. J., \& Wolery, M. (1991). Small group instruction: Guidelines for teachers of students with moderate to severe handicaps. Education and Training Mental Retardation, 26(1), 18-31. https://www.jstor.org/stable/23878629

Colozzi, G. A., Ward, L., \& Crotty, K. E. (2008). Comparison of simultaneous prompting procedure in 1:1 and small group instruction to teach play skills to preschool students with pervasive developmental disorder and developmental disabilities. Education and Training in Developmental Disabilities, 43(2), 226-248. https://www.jstor.org/stable/23879932

Crocket, K. (2007). Counselling supervision and the production of professional selves. Counselling and Psychotherapy Research, 7(1), 19-25. https://doi.org/10.1080/14733140601140402

Çattık, M., \& Odluyurt, S. (2017). The effectiveness of the smart board-based small-group graduated guidance instruction on digital gaming and observational learning skills of children with autism spectrum disorder. Turkish Online Journal of Educational Technology, 16(4), 84-102. http://www.tojet.net/articles/v16i4/16410.pdf

D’Ateno, P., Mangiapanello, K., \& Taylor, B. A. (2003). Using video modeling to teach complex play sequences to a preschooler with autism. Journal of Positive Behavior Interventions, 5(1), 5-11. https://doi.org/10.1177/10983007030050010801

Day, A. (2015). Comparing the efficacy of video modeling to in vivo modeling for teaching vocational skills to adolescents diagnosed with autism spectrum disorder [Master's thesis, Youngstown State University]. http://rave.ohiolink.edu/etdc/view?acc num=ysu1434021243

Dettmer, S., Simpson, R. L., Myles-Smith B., \& Ganz J. B. (2000). The use of visual supports to facilitate transitions of students with autism. Focus on Autism and Other Developmental Disabilities, 15(3), 163169. https://doi.org/10.1177/108835760001500307

Doyle, P. M., Gast, D. L., Wolery, M., Ault, M. J., \& Farmer, J. A. (1990). Use of constant time delay in small group instruction: A study of observational and incidental learning. The Journal of Special Education, 23(4), 369-385. https://doi.org/10.1177/002246699002300403

Ergenekon, Y., Tekin-İftar, E., Kapan, A., \& Akmanoglu, N. (2014). Comparison of video and live modeling in teaching response chains to children with autism. Education and Training in Autism and Developmental Disabilities, 49(2), 200-213. https://www.jstor.org/stable/23880605

Farmer, J. A., Gast, D. L., Wolery, M., \& Winterling, V. (1991). Small group instruction for students with severe handicaps: A study of observational learning. Education and Training in Mental Retardation, 26(2), 190201. https://www.jstor.org/stable/23878588

Fickel, K. M., Schuster, J. W., \& Collins, B. C. (1998). Teaching different tasks using different stimuli in heterogeneous small group. Journal of Behavioral Education, 8(2), 219-244. https://doi.org/10.1023/A:1022887624824

Garfinkle, A. N., \& Schwartz, I. S. (2002). Peer imitation: Increasing social interactions in children with autism and other developmental disabilities in inclusive preschool classrooms. Topics in Early Childhood Special Education, 22(1), 26-38. https://doi.org/10.1177/027112140202200103

Gena, A., Couloura, S., \& Kymissis, E. (2005). Modifying the affective behavior or preschoolers with autism using in-vivo or video modeling and reinforcement contingencies. Journal of Autism and Developmental Disorders, 35(5), 545-556. https://doi.org/10.1007/s10803-005-0014-9

Graetz, J. E., Mastropieri, M. A., \& Scruggs, T. E. (2006). Show time: Using video self-modeling to decrease inappropriate behavior. Teaching Exceptional Children, 38(5), 43-48.

Gürsel, O., Tekin-İftar, E., \& Bozkurt, F. (2006). Effectiveness of simultaneous prompting in small group: The opportunity of acquiring non-target skills through observational learning and instructive feedback. Education and Training in Developmental Disabilities, 41(3), 225-243. 
Hess, L. (2006). I would like to play but I don't know how: Case study of pretend play in autism. Child Language Teaching and Therapy, 22(1), 97-116. https://doi.org/10.1191/0265659006ct299oa

Hill, J., \& Gutwin, C. (2004). The MAUI toolkit: Groupware widgets for group awareness. Computer Supported Cooperative Work, 13(5), 539-571. https://doi.org/10.1007/s10606-004-5063-7

Holcombe, A., Wolery, M., \& Gast, D. L. (1994). Comparative single-subject research: Description of designs and discussion of problems. Topics in Early Childhood Special Education, 14(1), 119-145. https://doi.org/10.1177/027112149401400111

Ingersoll, B., \& Schreibman, L. (2006). Teaching reciprocal imitation skills to young children with autism using a naturalistic behavioral approach: Effects on language, pretend play, and joint attention. Journal of Autism and Developmental Disorders, 36(4), 487-505. https://doi.org10.1007/s10803-006-0089-y

Jahr, E., Eldevik, S., \& Eikeseth, S. (2000). Teaching children with autism to initiate and sustain cooperative play. Research in Developmental Disabilities, 21(2), 151-69. https://doi.org/10.1016/S0891-4222(00)00031-7

Kırcaali-İftar, G. (2013). Otizm spektrum bozukluğuna genel bakış. E. Tekin-İftar (Ed.), Otizm spektrum bozukluğu olan çocuklar ve eğitimleri [Children with autism spectrum disorders and their education] içinde (ss. 17-44). Vize Yayıncılık.

Landa, R. (2007). Early communication development and intervention for children with autism. Mental Retardation and Developmental Disabilities Research Reviews, 13(1), 16-25. https://doi.org/10.1002/mrdd.20134

Lane, J. (2009). Comparing video models to in vivo models as a way to teach play skills to children under the age of 3 [Master's thesis, University of Mary Washington]. http://hdl.handle.net/2047/d20000012

Ledford, J. R., Gast, D. L., Luscre, D., \& Ayres, K. M. (2008). Observational and incidental learning by children with autism during small group instruction. Journal of Autism and Developmental Disorders, 38(1), 86103. https://doi.org.10.1007/s10803-007-0363-7

Ledford, J. R., \& Wehby, J. H. (2015). Teaching children with autism in small groups with students who are atrisk for academic problems: Effects on academic and social behaviors. Journal of Autism and Developmental Disorders, 45(6), 1624-1635. https://doi.org/10.1007/s10803-014-2317-1

Lusardi, M. M., Levangie, P. K., \& Fein, B. D. (2002). A problem-based learning approach to facilitate evidencebased practice in entry-level health professional education. Journal of Prosthetics and Orthotics, 14(2), 40-50.

Ma, H. H. (2009). The effectiveness of intervention on the behavior of individuals with autism: A meta-analysis using percentage of data points exceeding the median of baseline phase (PEM). Behavior Modification, 33(3), 339-359. https://doi.org/10.1177/0145445509333173

MacDonald, R., Clark, M., Garrigan, E., \& Vangala, M. (2005). Using video modeling to teach pretend play to children with autism. Behavioral Interventions, 20(4), 225-238. https://doi.org/10.1002/bin.197

MacDonald, R., Sacramone, S., Mansfield, R., Wiltz, K., \& Ahearn, W. H. (2009). Using video modeling to teach reciprocal pretend play to children with autism. Journal of Applied Behavior Analysis, 42(1), 43-55. https://doi.org/10.1901/jaba.2009.42-43

Marcus, A., \& Wilder, D. A. (2009). A comparison of peer video modeling and self video modeling to teach textual responses in children with autism. Journal of Applied Behavior Analysis, 42(2), 335-341. https://doi.org/10.1901/jaba.2009.42-335

Massey, N. G., \& Wheeler, J. J. (2000). Acquisition and generalization of activity schedules and their effects on task engagement in a young child with autism in an inclusive pre-school classroom. Education Training Mental Retardation and Developmental Disabilities, 35(3), 326-335.

McDowell, L. S., Gutierrez Jr., A., \& Bennett, K. D. (2015). Analysis of live modeling plus prompting and video modeling for teaching imitation to children with autism. Behavioral Interventions, 30(4), 333-351. https://doi.org/10.1002/bin.1419 
Nicholls, L. (2019). Yoga and autism: The effectiveness of a year-long yoga programme: Its influence on physicality, communication, organisational skills and mood in a small group of school-age pupils [Doctoral dissertation, University of Strathclyde]. http://digitool.lib.strath.ac.uk/R/?func=dbin-jumpfull\&object_id=33376

Morrison, R. S., Sainato, D. M., Benchaaban, D., \& Endo, S. (2002). Increasing play skills of children with autism using activity schedules and correspondence training. Journal of Early Intervention, 25(1), 58-72. https://doi.org/10.1177/105381510202500106

Odluyurt, S. (2013). Kaynaştırmaya devam eden otistik özellikler gösteren çocuklara kurallı oyun öğretiminde akranları tarafından doğrudan model olma ve videoyla model olma öğretiminin etkilerinin karşılaştırılması [A comparison of the effects of direct modeling and video modeling provided by peers to students with autism who are attending in rural play teaching in an inclusive setting]. Kuram ve Uygulamada Eğitim Bilimleri, 13(1), 536-540.

Özen, A., Batu, E. S., \& Birkan, B. (2012). Teaching skills play to children with autism through video modeling: Small group arrangement and observational learning. Education and Training in Autism and Developmental Disabilities, 47(1), 84-96. https://www.jstor.org/stable/23880564

Palmen, A., Didden, R., \& Arts, M. (2008). Improving question asking in high-functioning adolescents with autism spectrum disorders: Effectiveness of small-group training. Autism, 12(1), 83-98. https://doi.org/10.1177/1362361307085265

Paterson, C. R., \& Arco, L. (2007). Using video modeling for generalizing toy play in children with autism. Behavior Modification, 31(5), 660-681. https://doi.org/10.1177/0145445507301651

Rao, S. M., \& Gagie, B. (2006). Learning through seeing and doing visual supports for children with autism. Teaching Exceptional Children, 38(6), 26-33. https://doi.org/10.1177/004005990603800604

Reagon, K. A., Higbee, T. S., \& Endicott, K. (2006). Teaching pretend play skills to a student with autism using video modeling with a sibling as model and play partner. Education and Treatment of Children, 29(3), 517-528.

Rubin, K. H., Maioni, T. L., \& Hornung, M. (1976). Free play behaviors in middle-and lower-class preschoolers: Parten and Piaget revisited. Child Development, 47(2), 414-419. https://doi.org/10.2307/1128796

Rutherford, M. D., Young, G. S., Hepburn, S., \& Rogers, S. J. (2007). A longitudinal study of pretend play in autism. Journal of Autism and Developmental Disorders, 37(6), 1024-1039. https://doi.org/10.1007/s10803-006-0240-9

Saadatzi, M. N., Pennington, R. C., Welch, K. C., \& Graham, J. H. (2018). Small-group technology-assisted instruction: Virtual teacher and robot peer for individuals with autism spectrum disorder. Journal of Autism and Developmental Disorders, 48(11), 3816-3830. https://doi.org/10.1007/s10803-018-3654-2

Schloss, P. J., \& Smith, M. A. (1994). Applied behavior analysis in the classroom. Allyn and Bacon.

Schwartz, I. S., \& Baer, D. M. (1991). Social validity assessments: Is current practice state of the art? Journal of Applied Behavior Analysis, 24(2), 189-204. https://doi.org/10.1901/jaba.1991.24-189

Sherer, M., Pierce, K., Paredes, S., Kisacky, K., Ingersoll, B., \& Schreibman, L. (2001). Enhancing conversation skills in children with autism via video technology. Behavior Modification, 25(1), 140-159. https://doi.org/10.1177/0145445501251008

Shelton, B. S., Gast, D. L., Wolery, M., \& Winterling, V. (1991). The role of small group instruction in facilitating observational and incidental learning. Language, Speech, and Hearing Services in the School, 22(3), 123133. https://doi.org/10.1044/0161-1461.2203.123

Singer, D. G., Golinkof, R. M., \& Hirsh-Pasek, K. (2006). Play=learning: How play motivates and enhances children's cognitive and social-emotional growth. Oxford University Press.

Stahmer, A. C., \& Schreibman, L. (1992). Teaching children with autism appropriate play in unsupervised environments using a self-management treatment package. Journal of Applied Behavior Analysis, 25(2), 447-459. https://doi.org/10.1901/jaba.1992.25-447 
Stahmer, A. C., Ingersoll, B., \& Carter, C. (2003). Behavioral approaches to promoting play. Autism: The International Journal of Research and Practice, 7(4), 401-413. https://doi.org/10.1177/1362361303007004006

Sucuoğlu, B. (2013). Engelli çocuklarda oyun gelişimi: Otistik çocuklar. U. Tüfekçioğlu (Ed.), Çocukta oyun gelişimi [Play development in the child] içinde (ss. 183-194). Anadolu Üniversitesi Açıöŏretim Fakültesi Yayınları.

Taheri-Torbati, H., \& Sotoodeh, M. S. (2019). Using video and live modelling to teach motor skill to children with autism spectrum disorder. International Journal of Inclusive Education, 23(4), 405-418. https://doi.org/10.1080/13603116.2018.1441335

Tekin, E., Kırcaali-İftar, G., Birkan, B., Uysal, A., Yıldırım, S., \& Kurt, O. (2001). Using constant time delay to teach leisure skills to children with developmental disabilities. Mexican Journal of Behavior Analysis, 27(3), 337-362. http://dx.doi.org/10.5514/rmac.v27.i3.23581

Tekin-İftar, E., \& Birkan, B. (2010). Small group instruction for students with autism: General case training and observational learning. The Journal of Special Education, 44(1), 50-63. https://doi.org/10.1177/0022466908325219

Tekin-İftar, E. (2012). Davranış kayıt teknikleri. E. Tekin-İftar (Ed.), Ĕgitim ve davranış bilimlerinde tek-denekli araştırmalar [Single-subject research methodology in educational and behavioral sciences] içinde (ss. 69-108). Türk Psikologlar Derneği.

Thompson, J. L., Wood, C. L., Preston, A., \& Stevenson, B. (2019). Teaching unison responding during smallgroup direct instruction to students with autism spectrum disorder who exhibit interfering behaviors. Education and Treatment of Children, 42(1), 1-23. https://doi.org.10.1353/etc.2019.0001

Tryon, A. S., \& Keane, S. P. (1986). Promoting imitative play through generalized observational learning in autistic-like children. Journal of Abnormal Child Psychology, 14(4), 537-549.

Tüfekçioğlu, U. (2013). Okulöncesi eğitimde oyun ve önemi. U. Tüfekçioğlu (Ed.), Çocukta oyun gelişimi [Play development in the child] içinde (ss. 2-34). Anadolu Üniversitesi Açıköğretim Fakültesi Yayınları.

Vuran, S., \& Sönmez, M. (2008). Sosyal geçerlik kavramı ve Türkiye’de özel eğitim alanında yürütülen lisansüstü tezlerde sosyal geçerliğin değerlendirilmesi [Concept of social validity and assessment of graduate theses in terms of social validity conducted in special education field in Turkey]. Ankara Üniversitesi Eğitim Bilimleri Fakültesi Özel Ĕgitim Dergisi, 9(1), 55-65. https://doi.org/10.1501/Ozlegt_0000000114

Wilson, K. P. (2013). Teaching social-communication skills to preschoolers with autism: Efficacy of video versus in vivo modeling in the classroom. Journal of Autism and Developmental Disorders, 43(8), 1819-1831. https://doi.org/10.1007/s10803-012-1731-5

Wolery, M., Ault, M. J., \& Doyle, P. M. (1992). Teaching students with moderate and severe handicaps: Use of response prompting strategies. Longman.

Xu, Y. (2010). Children's social play sequence: Parten's classic theory revisited. Early Child Development and Care, 180(4), 489-498. https://doi.org/10.1080/03004430802090430

Zirpoli, T. J., \& Melloy, K. J. (1997). Behavior management: Applications for teachers and parents. Merrill. 


\section{Ankara University Faculty of Educational Sciences Journal of Special Education}

2022, 23(3), 537-563

\title{
Comparison of Live Modeling and Video Modeling on Teaching Symbolic Plays to Children with Autism Spectrum Disorder in Small Groups*
}

\author{
Nuray Öncül (D1
}

\author{
İlknur Çifci-Tekinarslan ${ }^{(D)} 2$
}

\begin{abstract}
Introduction: It is suggested in literature there is a need for interventions in developing symbolic play behaviors of children with autism spectrum disorder (ASD) and the effectiveness of various methods are examined. The purpose of this study is to compare the effectiveness and efficiency of live modeling and video modeling on teaching symbolic plays to children with autism spectrum disorder in small groups.

Method: This study employed an adaptive alternating treatments design. The independent variables were live video modeling and video modeling presented in small group instruction. Also, the dependent variables were the symbolic play behaviors of acting as a waiter and as a barber.

Findings: The research findings demonstrated that both live modeling and video modeling presented in small group instruction were effective in acquisition, maintenance, and generalization of symbolic plays of children with autism spectrum disorder. Video modeling was more effective than live modeling for acquisition; live modeling was more effective than video modeling for maintenance; and there was no difference between the methods for generalization.
\end{abstract}

Discussion: Although it is known that children with ASD have impairments especially in playing symbolic play, it was planned to teach two games in the research, and the program was taught to learn with a video modeling and a live modeling program to teach small group instruction. Learning how to play the symbolic play of the vehicle with the autism spectrum disorder through a search in the process in question serves the purpose of the research. This purpose has been discussed in a way to include the results, and suggestions have been made for future research.

Keywords: Live modeling, video modeling, symbolic play, teaching small group, autism spectrum disorder.

To cite: Öncül, N., \& Çifci-Tekinarslan, İ. (2022). Comparison of live modeling and video modeling on teaching symbolic plays to children with autism spectrum disorders in small groups. Ankara University Faculty of Educational Sciences Journal of Special Education, 23(3), 537-563. https://doi.org/10.21565/ozelegitimdergisi.783396

\footnotetext{
*This study is based on the doctora thesis of the first author submitted to the Institute of Educational Sciences at Bolu Abant İzzet Baysal University.

${ }^{1}$ Corresponded Author: Assist. Prof., Anadolu University, E-mail: noncul@ anadolu.edu.tr, https://orcid.org/0000-0003-0099$\underline{0326}$

${ }^{2}$ Prof., Bolu Abant İzzet Baysal University, E-mail: ilknur_cifci@ hotmail.com, https://orcid.org/0000-0001-5028-3289
} 


\section{Introduction}

The development of social interaction and communication skills is challenging for children with autism spectrum disorder (ASD; Gena \& Couloura, 2005), which restricts the possibilities for reciprocal engagement with other children, therefore driving them to socially retreat. Play activities of children with ASD vary significantly from other children's play activities (Rutherford et al., 2007). Children with ASD play with toys in unusual ways. They demand a consistent schedule or framework and show strong interest in uncommon activities with their peers (Gena et al., 2005; Paterson \& Arco, 2007). When children with ASD are permitted to play with their peers, they may have behavioral difficulties. They are in the same setting with typically developing youngsters, yet they make little effort to communicate with others (Boutot et al., 2005; Terpstra \& Tamura, 2007). Typically developing children usually acquire appropriate playing habits, such as participation in games, social interaction, playing individually with toys, and toy sharing (Paterson \& Arco, 2007). However, children with ASD should be taught these abilities methodically. One of the most commonly utilized ways to teach play skills to children with ASD is the method by which a child observes a target behavior and imitates what they have noticed (Bandura et al.1961; Schloss \& Smith, 1994; Zirpoli \& Melloy, 1997). Video modeling (VM) is an extensively utilized method for children with ASD. The teacher models target behavior in person (i.e., in-vivo modeling) and the child watches the modeling in video format, then imitates the modeled behavior (Bellini \& Akullian, 2007). In video selfmodeling (VSM), learners view video recordings of themselves performing target behaviors, then demonstrate these target behaviors in person (Charlop-Christy et al., 2000; Graetz et al., 2006). Mixed data are available on whether models are more efficient and user-friendly (Ergenekon et al., 2014; Paterson \& Arco, 2007). Further research is thus necessary to evaluate teaching efficiency and efficacy with different models. Therefore, the current study investigated the efficiency and efficacy of teaching symbolic play skills to children with ASD in a smallgroup instructional format, using live modeling or video modeling. There is also a limited number of studies in which children with ASD have been taught in small-group instructional formats (Carnahan et al., 2009; Colozzi et al., 2008; Kamps et al., 1992; Ledford et al., 2008; Özen et al., 2012; Palmen et al., 2008; Tekin-İftar \& Birkan, 2010). The objective of this study was to contribute to the literature on teaching in small-group formats. Another unusual element of this study is that prompting and positive reinforcement were not employed in addition to teaching through modeling. When the aforementioned techniques are used, it might be difficult to determine if efficacy results originate from VM or live modeling. Therefore, the field needs studies that do not use prompts and positive reinforcement but only instruction with modeling. The current research can fill the gap in this area of research.

\section{Method}

This study utilized an adaptive alternative treatments design (AATD) to investigate the comparative efficacy and effectiveness of live modeling and VM to teach children with ASD symbolic play skills in smallgroup instructional formats.

\section{Participants}

The research participants included three children with ASD, three preservice teachers, three video modelers, and 64 preservice teachers who offered their opinions on the social validity of this research. Three boys with ASD were involved as subjects in this study. Eligibility criteria included: (a) no diagnosis aside from ASD, (b) at least $5 \mathrm{~min}$ of engaging in an activity, (c) video viewing for at least $5 \mathrm{~min}$, (d) ability to follow verbal instructions, (e) motor and verbal imitation of behaviors, (f) responding to group activities, and (g) regular school attendance.

Target behaviors were utilized to compare teaching with live modeling and VM. Information from the participating adults indicated that the child participants knew and favored the models who participated in the live modeling instruction. The models featured in the VM teaching were preferred from the unknown subjects of the adults.

\section{Setting and Materials}

The research was conducted in a Special Education Center. Various materials were used during the research. It is possible to classify these materials as scenarios, video footage, tools used in games, and materials used in data collection. 


\section{Research Design}

The study employed an AATD, one of the single-subject study models, to to evaluate the comparative teaching efficiency of live modeling and VM to teach children with ASD symbolic play skills (Holcombe et al., 1994; Tekin-İftar, 2012). To achieve internal validity, we took care to ensure that the dependent variables were equivalent in terms of the level of difficulty, dependent from one another, and functional. To control outside factors were informed the teachers of the children about the target behaviours and asked them not to instruct them on this topic.

\section{Variables}

Two dependent variables were measured in this study: the symbolic play behaviors of acting as a waiter and as a barber. The dependent variable was selected together with the children's teachers from among the goals included in their individualized training programs. The independent variables were teaching with live modeling and teaching with VM teaching.

\section{Procedure}

Procedure comprised of (a) baseline sessions, (b) instructional sessions, (c) probe sessions, (d) generalization sessions, (e) follow-up sessions, and (f) observed learning sessions. All sessions were conducted in small-group instructional formats during the experimental procedure. Both modeling sessions were conducted 3 days a week, with two sessions a day, in the morning and in the afternoon. Each instructional session was followed by a trial. The response interval of $5 \mathrm{sec}$. was fixed. No prompts, feedback, or positive reinforcement to the participants in any sessions of this experimental procedure to ensure experimental control and to show that variation in the dependent variables was exclusively caused by specific independent variables. Observational sessions were also conducted to evaluate the extent to which monitoring was carried out. Each participant was assigned two different roles in the teaching sessions, and we measured the extent to which the participants learned by witnessing roles other than their own.

\section{Data Collection}

Four data types were collected in this study: data on effectiveness, efficiency, social validity, and reliability. Effectiveness data obtained in the study were analyzed in two ways: visual analysis and effect size calculation. In order to determine whether there was a difference in efficiency between teaching with live modeling and teaching with VM, data were collected on (a) the total number of trials to criterion, (b) the total number of sessions that took place to criterion, (c) the total number of errors that occurred to criterion, and (d) the total teaching time to criterion. These data were analyzed and reported descriptively. The social validity data were analyzed quantitatively through descriptive analysis.

\section{Findings}

\section{Effectiveness Findings}

Participants were given the code names Kaan, Salih, and Selim. The first subject, Kaan's, performance level playing waiter and barber roles during the baseline 1 phase was $0 \%$. During the intervention implementation phase, Kaan exhibited improvements in both games. He fulfilled the requirements and answered correctly at $85 \%$; during the next stage, he performed at $100 \%$ for the waiter game and at $85.7 \%$ for the barber game. At the end of 30 teaching sessions, Kaan met the performance criterion with live modeling. Kaan met the performance criterion with VM teaching for the waiter game at the conclusion of 28 training sessions, and he played the barber game at $85 \%$ or above for three subsequent sessions.

The second subject, Salih, showed $0 \%$ correct responding in the baseline phase for both the waiter and the barber games. Salih showed improvement in both games during the intervention implementation phase and he performed correctly at the level of $85 \%$ thus meeting the performance criterion; in the monitoring phase, he responded at $100 \%$ accuracy in the waiter game and at $85.7 \%$ accuracy in the barber game.

At the end of 28 live modeling teaching sessions, Salih met the performance criterion. At the end of the $24 \mathrm{VM}$ lessons in waiter play, he scored $85 \%$ and higher in the barber game for three consecutive sessions. Instruction proceeded until all participants met the performance criterion. To determine the extent of functional relation, average performance data were analyzed. Participants performed at 79\% accuracy with live modeling and at $96 \%$ with VM. 
Selim was the third subject. Performance data were collected in the baseline, intervention, and follow-up phases for Selim. His performance level for both the waiter and the barber games was $0 \%$ during the baseline phase. During the intervention phase, Selim showed improvement in both games and correctly met the performance criterion at the $100 \%$ level in the waiter game and $88.8 \%$ in the barber game.

At the conclusion of 29 lessons when teaching with live modeling was offered, Selim met the performance criterion. In three consecutive barber sessions, Selim performed at $85 \%$ and above after $18 \mathrm{VM}$ teaching sessions. Average performance data were calculated to determine functional relations, with an average of $80 \%$ correct responding with live modeling and $100 \%$ accurate performance with VM.

The results of Kaan's, Salih's, and Selim's accurate responding in the pretest and posttest generalization probes $\mathrm{f}$ for the barber and waiter games are displayed. During the pretest generalization session, Kaan showed no correct responses in either the waiter or the barber game; he performed at $85.7 \%$ correct responding for both games and he generalized playing the games with other individuals and instruments in the posttest generalization session.

Salih did not show correct responding in the waiter or barber game in the generalization pretest session; in the generalization posttest session, he scored $85.7 \%$ for the waiter game and $92.8 \%$ for the barber game.

Selim showed correct responding at $5.8 \%$ for the waiter game and $5.5 \%$ for the barber game in the generalization pretest session; in the generalization posttest session, he generalized the games to different people and tools by correctly responding at $100 \%$ in the waiter game and at $88.8 \%$ in the barber game.

\section{Findings Related to Efficiency}

The number of trials, sessions, and errors as well as total teaching time were analyzed once all participants reached the performance criterion to compare the efficiency of teaching symbolic play skills with live modeling and VM in small-group instructional formats.

The total number of trials and sessions conducted with live modeling was 30 for Kaan, 28 for Salih, and 28 for Selim. The number of errors to performance criterion with live modeling was 133 for Kaan, 179 for Salih, and 203 for Selim. Total live-modeling teaching time to performance criterion was 1 hour 57 min 36 s for Kaan, 1 hour $49 \mathrm{~min} 00 \mathrm{sec}$ for Salih and 1 hour $52 \mathrm{~min} 00 \mathrm{sec}$ for Selim. The total number of trials and sessions conducted with VM until the performance criterion was met was 28 for Kaan, 24 for Salih, and 18 for Selim. The number of errors to performance criterion with VM was 155 for Kaan, 133 for Salih, and 115 for Selim. Total VM teaching time to performance criterion was 2 hours $32 \mathrm{~min} 39 \mathrm{sec}$ for Kaan, 2 hours $12 \mathrm{~min} 17 \mathrm{sec}$ for Salih, and 1 hour 43 $\min 33 \mathrm{sec}$ for Selim.

\section{Findings Related to Observational Learning}

Kaan's observational learning performance for the roles of waiter and customer in the "waiter game" was at $0 \%$ for both roles in the pretest session. Kaan's observational learning of the waiter role was at $85 \%$ in the posttest session, and his learning by observation regarding the customer role was at $100 \%$ in the posttest session. Kaan's performance levels in the pretest session regarding the roles of barber and apprentice were both at $0 \%$. Kaan's learning by observing the barber role was at $85 \%$ in the posttest session and learning by observing the apprentice role in the posttest session was at $78 \%$.

Salih's learning by observing the roles of manager and customer in the waiter game was at $0 \%$ in the pretest session. Salih's learning by observing the role of manager was $85 \%$ in the posttest session; his correct responding for learning by observing the customer role was $85 \%$ in the posttest session. Salih's performance level after learning by observing the apprentice and customer roles in the barber game was $0 \%$ in the pre-test session. Salih's learning by observing the role of apprentice was at $89 \%$ in the posttest session; after observing the customer role, his correct responding was at $96 \%$ in the posttest session.

Selim's learning by observing the roles of manager and waiter in the waiter game was at $0 \%$ in the pretest session. His learning by observing the role of barber was at the level of $71 \%$ in the posttest session, and his performance after learning by observing the customer role was $79 \%$ in the posttest session. Selim's observational learning performance regarding the roles of barber and customer in the barber game was at $0 \%$ in the pretest session regarding both the barber and the customer roles. Selim performed the role of barber at the $85 \%$ level in the posttest session after observing the role of barber in the teaching sessions; his learning by observing the customer role showed correct responding at $78 \%$ in the posttest session. 


\section{Findings Related to Social Validity}

Individual interviews with the participants yielded social validity data. During the interviews, the participants were asked four structured interview questions. In the first question, the subjects were asked, "Are you happy to participate in this study?" All of the subjects answered this question with "Yes." The second question regarded the participants' preferences for the teaching methods used in the study: "Is it more enjoyable to watch the games you learned from the computer (VM) or is it more enjoyable to watch live models?" All of the subjects answered this question by expressing that they found it more enjoyable to watch from the computer (VM). In the third question, regarding the preference of the games taught in the research, "Which game did you like playing better: the waiter or the barber game?" Two of the subjects stated that they liked playing the barber game and one stated that he liked playing the waiter game more. When the fourth question, "Would you like to take part in such a study again?" was asked, all of the subjects expressed that they would like to take part in such a study in the future.

\section{Discussion}

The purpose of this study was to compare the effectiveness and efficiency of teaching symbolic play skills to children with ASD using live modeling and VM in the context of small-group instructional formats. The study aimed at assessing the comparative efficacy of teaching symbolic play skills to children with ASD via live-modeling and VM teaching during acquisition, maintenance, and generalization phases, and if the comparative efficiency between the two teaching procedures is significant. In addition, this study measured the comparative effects of live modeling and VM on observational learning as children with ASD were taught symbolic play skills in small-group formats via.

The results of this research demonstrate the comparative effectiveness of live- modeling instruction and VM in teaching symbolic play skills to children with ASD. The results of the study also show that teaching with VM in a small-group instructional format is more effective than teaching with live modeling during the acquisition phase of symbolic play skills. Furthermore, the results demonstrate that the effectiveness of live modeling and VM differs. Two participants preferred being taught with VM and one boy preferred being taught with live modeling. The results of this study indicate that teaching with live modeling teaching was more effective than VM teaching for skills maintenance and generalization. Furthermore, no significant difference existed between live-modeling teaching and VM teaching.

Evidence shows that both live-modeling and VM instruction are successful in teaching children with ASD symbolic play skills. The results of this research support previous empirical conclusions demonstrating that both livemodeling and VM teaching are helpful in teaching children with ASD to play games. (Boudreau \& D'Entremont, 2010; D'Ateno et al., 2003; Jahr et al., 2000; MacDonald et al., 2005; Ozen et al., 2012; Paterson \& Arco, 2007; Reagon et al., 2006; Tryon \& Keane, 1986). The findings obtained in this study show that teaching with VM is more effective for all subjects compared to teaching with live modeling but there is only a slight difference between them. While this finding is similar to Charlop-Christy et al.'s (2000) study demonstrating that teaching with VM provided faster acquisition than teaching with live modeling in teaching children with ASD how to play games, it varies from other research findings that show that teaching with live modeling and VM teaching are equally effective (Ergenekon et al., 2014; Gena et al., 2005; Odluyurt, 2013).

Not using prompts, feedback, or positive reinforcement in addition to teaching with live modeling and teaching with VM increased the internal validity of the study, showing the effects of the independent variables without interference by confounding variables. The social validity data collected from preservice teachers were positive, and the teacher candidates stated that symbolic play contributed considerably to the social development of children with ASD, teaching new different behaviors, developing their imagination, and learning to play.

Besides the strengths discussed in the report of the study's findings, there are some limitations. One important limitation of this research is the differentiation of the two types of modeling (i.e., live modeling and VM) used in teaching. In addition, although the models used in the live-modeling teaching sessions were people known by the child participants, the models used in the VM teaching sessions were people unknown to the participants, which can be expressed as the second important limitation of the study.

Considering the findings and limitations of the study, some recommendations for further research are made. In this study, the people who modeled the roles taught with both live modeling and VM teaching were adults. Future researchers might plan to compare these two teaching approaches using peers as models. In addition, in future studies researchers might consider using the same models for both live-modeling and VM teaching approaches.

\section{Authors' Contributions}

The authors collaboratively performed the tasks of determining the subject of the manuscript, research design, data collection, data analysis and reporting of the study. 